OECD Health Working Papers No. 66

\title{
The Role of Fiscal Policies in Health Promotion
}

\author{
Franco Sassi,
}

Annalisa Belloni,

\section{Chiara Capobianco}


Organisation de Coopération et de Développement Économiques

Organisation for Economic Co-operation and Development

11-Dec-2013

DIRECTORATE FOR EMPLOYMENT, LABOUR AND SOCIAL AFFAIRS

English text only

HEALTH COMMITTEE

Cancels \& replaces the same document of 10 December 2013

\section{Health Working Papers}

\section{OECD HEALTH WORKING PAPER NO. 66}

The Role of Fiscal Policies in Health Promotion

Franco Sassi, Annalisa Belloni, Chiara Capobianco

JEL Classification: H2, I18, I31, Q18

All Health Working Papers are now available through the OECD's Inernet Website at http://www.oecd.org/health/workingpapers

JT03350329

Complete document available on OLIS in its original format

This document and any map included herein are without prejudice to the status of or sovereignty over any territory, to the delimitation of international frontiers and boundaries and to the name of any territory, city or area. 


\title{
DIRECTORATE FOR EMPLOYMENT, LABOUR AND SOCIAL AFFAIRS
}

\author{
www.oecd.org/els
}

\section{OECD HEALTH WORKING PAPERS}

\author{
http://www.oecd.org/health/workingpapers
}

This series is designed to make available to a wider readership health studies prepared for use within the OECD. Authorship is usually collective, but principal writers are named. The papers are generally available only in their original language - English or French - with a summary in the other.

Comment on the series is welcome, and should be sent to the Directorate for Employment, Labour and Social Affairs, 2, rue André-Pascal, 75775 PARIS CEDEX 16, France.

The opinions expressed and arguments employed here are the responsibility of the author(s) and do not necessarily reflect those of the OECD.

\author{
Applications for permission to reproduce or translate \\ all or part of this material should be made to: \\ Head of Publications Service \\ OECD \\ 2, rue André-Pascal \\ 75775 Paris, CEDEX 16 \\ France \\ Copyright OECD 2013
}




\section{ACKNOWLEDGEMENTS}

This paper was written as part of the OECD Economics of Prevention programme, which is funded through regular contributions from OECD member countries, and has benefitted from a voluntary contribution from Korea. The authors wish to acknowledge substantial contributions to the background work for this paper from Michele Cecchini, and helpful comments from Mark Pearson, colleagues in the OECD Directorates of Economics, Trade and Agriculture, and the Centre for Tax Policy and Administration, members of the OECD Health Committee and Expert Group on the Economics of Prevention, including representatives of the Business and Industry Advisory Committee to the OECD (BIAC) and the United States Council for International Business (USCIB). In addition, the authors would like to thank Timo Stahl (THL) and Kwok-Cho Tang (WHO) for comments provided in the preparation of a background paper for the $8^{\text {th }}$ Global Conference on Health Promotion (Helsinki, June 2013), and Gauden Galea (WHO Europe) for his advice and suggestions in the initial phase of the work. Judy Zinnemann provided editorial assistance and support throughout. The authors remain responsible for any errors and omissions. The opinions expressed in the paper are the responsibility of the authors and do not necessarily reflect those of the OECD or its Member Countries. 


\begin{abstract}
Taxes and other fiscal measures on health-related commodities are in widespread use. Alcoholic beverages and tobacco products have been subjected to taxation for a long time in most countries. Several OECD governments have passed legislation to increase existing taxes or to introduce new taxes on foods high in salt, sugar or fat in the past few years. Traditionally, commodity taxes have been primarily seen as a source of fiscal revenues and a way to address consumption externalities. More recently, an increased emphasis has been placed on the potential health benefits of commodity taxation, as evidence emerged of the adverse public health, social and economic consequences of the consumption of a range of commodities.

This paper provides a review of the theoretical arguments and empirical evidence on the key factors that governments must address when considering the adoption of fiscal measures for health promotion, highlighting the strengths, as well as the limitations and pitfalls, of specific measures. The main focus of this paper is on taxes on health-related commodities, although a range of other fiscal measures may potentially be used in health promotion.

Existing evidence of effects on consumption and health outcomes points to the conclusion that taxes on healthrelated commodities can be a powerful tool for health promotion, although the variety and complexity of the effects they generate require careful consideration by policy makers who intend to adopt new taxes or reform existing ones. The arguments in support of taxes being used to attain public health objectives are strong for tobacco products and alcoholic beverages, but less clear-cut for foods, in which case the value of using taxes is highly dependent on their design and on the context in which they would be applied.
\end{abstract}

\title{
Résumé
}

Les taxes et autres mesures fiscales sur les produits liés à la santé sont largement utilisées. Boissons alcoolisées et produits du tabac ont été soumis à la fiscalité depuis longtemps dans la plupart des pays. Plusieurs gouvernements de l'OCDE ont adopté ces dernières années des lois visant à augmenter les taxes existantes ou à en créer de nouvelles sur les aliments à haute teneur en sel, sucre ou matières grasses. Traditionnellement, les taxes à la consommation ont été essentiellement vues comme une source de recettes fiscales et un moyen de résoudre des externalités de consommation. Plus récemment, on a davantage insisté sur les potentiels bienfaits sur la santé des taxes à la consommation, alors qu'il est de plus en plus apparent qu'il y a des conséquences économiques, sociales et de santé publique négatives à consommer une certaine catégorie de produits.

Ce document passe en revue les arguments théoriques et les preuves empiriques venant défendre les facteurs clés que les gouvernements doivent prendre en compte lorsqu'il s'agit d'envisager l'adoption de mesures fiscales pour la promotion de la santé, en soulignant les points forts, ainsi que les limites et les pièges, de mesures spécifiques. L'accent est mis dans ce document sur les taxes à la consommation de produits liés à la santé, mais une série d'autres mesures fiscales peut potentiellement être utilisée pour promouvoir la santé.

Le document conclut que, sur la base des preuves disponibles des effets sur la consommation et des résultats sur la santé, les taxes sur les produits liés à la santé peuvent être un outil puissant pour la promotion de la santé, bien que la variété et la complexité des effets qu'elles génèrent obligent les pouvoirs publics qui envisagent d'adopter de nouvelles taxes ou d'en revoir certaines à bien réfléchir. Les arguments en faveur des taxes utilisées pour atteindre des objectifs de santé publique sont forts pour le tabac et les boissons alcoolisées, mais ceci est moins évident pour les aliments, auquel cas la valeur de l'utilisation des taxes est fortement liée à leur conception et au contexte dans lequel elles seraient appliquées. 


\section{TABLE OF CONTENTS}

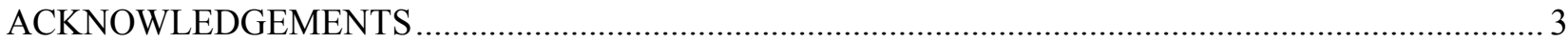

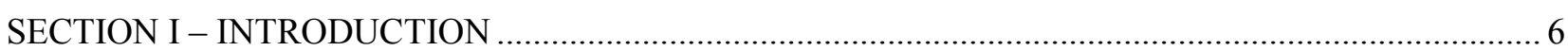

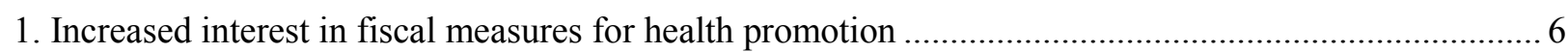

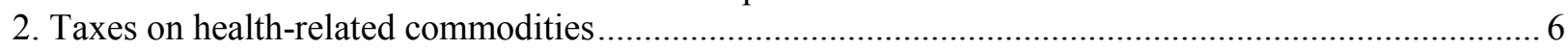

3. The rationale for the use of commodity taxes in health promotion.................................................... 7

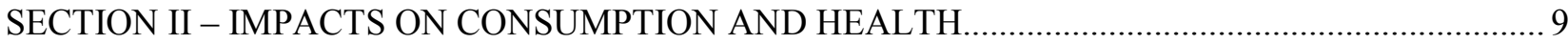

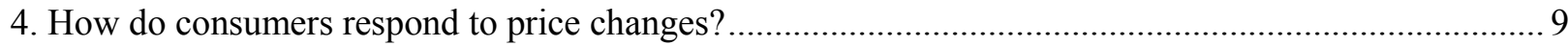

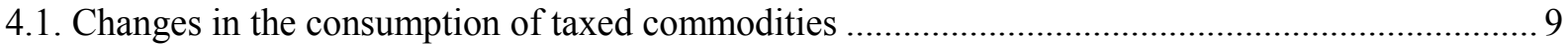

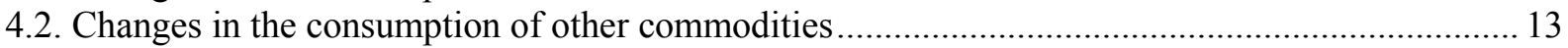

5. To what extent do fiscal measures affect prices? ............................................................................ 14

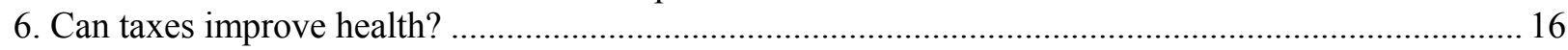

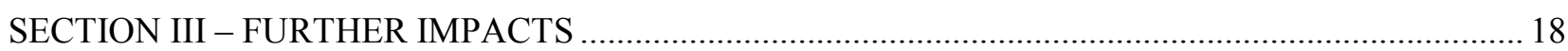

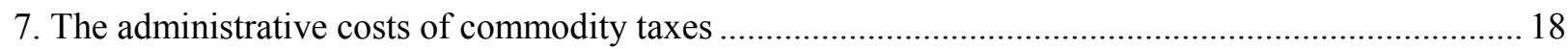

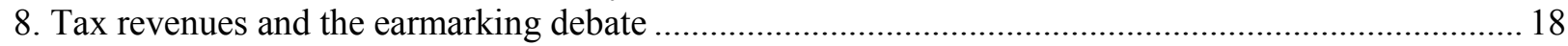

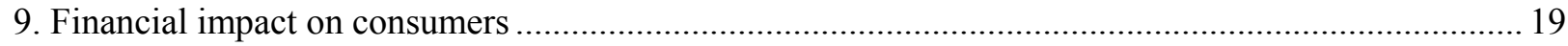

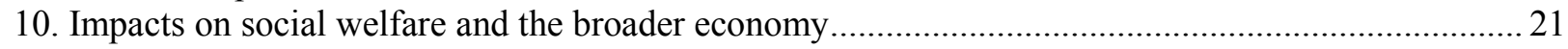

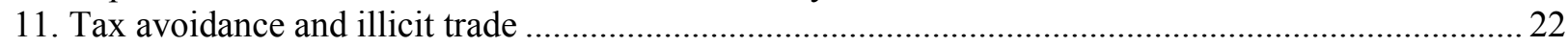

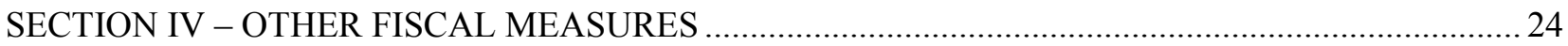

12. Fiscal measures potentially available for health promotion ........................................................... 24

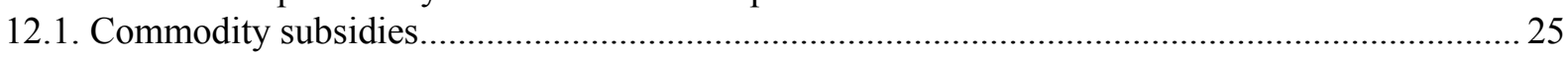

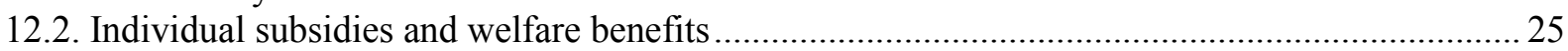

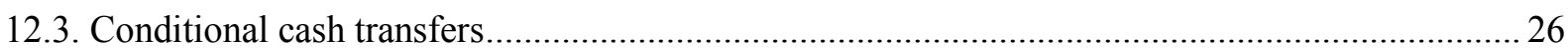

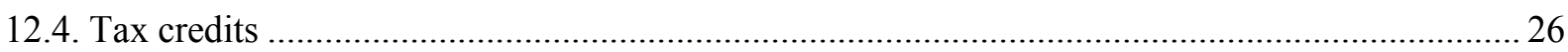

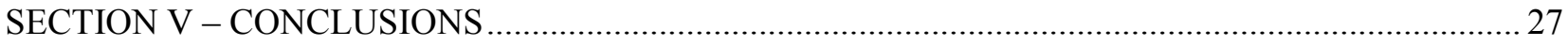

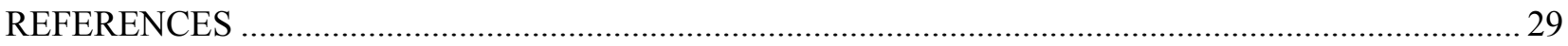

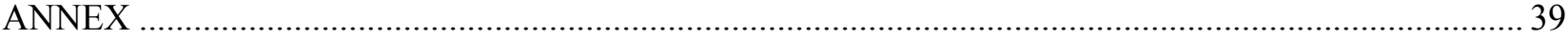

\section{Tables}

Table 1. Own price elasticity of the demand for selected foods and non-alcoholic beverages........... 12 Figures

Figure 1. Household expenditure on health-related commodities, UK and US ............................... 20

Figure 2. Unrecorded alcohol consumption in a selection of countries at different income levels...........23

Figure 3. Fiscal measures with a potential for use in health promotion................................................ 24 


\section{SECTION I - INTRODUCTION}

\section{Increased interest in fiscal measures for health promotion}

1. Governments may use fiscal policies to influence the consumption of health-related commodities (e.g. alcohol, tobacco, certain foods and non-alcoholic beverages). Fiscal policies include a wide range of measures, involving either the collection of revenues (typically taxation) or the spending of those revenues, aimed at providing appropriate incentives for consumers. This paper will focus primarily on commodity taxes, the types of fiscal measures most widely used to influence individual consumption. Examples of other fiscal measures that may be used in the pursuit of public health goals are discussed in Section IV.

2. When taxes are designed to pursue public health goals, they aim at raising prices above some consumers' willingness to pay, in order to put off those consumers and lead others to cut their consumption. Taxes and other fiscal measures on health-related commodities are in widespread use throughout the globe, and have been so for centuries. The taxation of alcoholic beverages, for instance dates back at least two thousand years, with levies imposed on wine merchants during the Han period in ancient China. The motivation for such taxes has been more often linked to the fiscal revenues generated than to their potential public health benefits. However, especially in more recent times, an increased emphasis has been placed on the latter by many governments, as evidence emerged of the adverse public health, social and economic consequences of the consumption of certain commodities.

3. An increasing number of governments are seeking to expand their use of fiscal measures to promote healthier behaviours. Many governments are increasing or rationalising their use of taxes on tobacco and alcohol products. A number of countries apply different tax rates to certain food categories, and some have specific taxes on foods high in salt, sugar or fat, and on sugary drinks. Only in the past two years, countries such as Denmark, Hungary, Finland, France and Mexico introduced taxes on foods and non-alcoholic beverages deemed potentially unhealthy ${ }^{1}$.

4. The aim of this paper is to review the theoretical arguments and the empirical evidence on the key factors that governments must address when considering the adoption of fiscal measures for health promotion, highlighting the strengths, as well as the limitations and pitfalls, of specific measures.

\section{Taxes on health-related commodities}

5. Indirect taxes on health-related commodities can take different forms. Excise duties, either per unit of product or value, are among the most common, along with value added taxes and sales taxes, applied as a percentage of sale prices. Excise taxes per unit of product are simpler to administer, but they have to be regularly adjusted for inflation, otherwise their real value will erode over time.

6. Excise rates and tax bases vary widely across countries. For alcoholic beverages, excise duties are often based on alcohol content. Rates applied in OECD countries for different beverages, as well as tobacco products, are shown in the Annex. For instance excise rates for wine range from values close to zero in Austria, Czech Republic, Germany, Greece, Hungary, Israel, Italy, Luxembourg, Portugal, Slovak Republic, Slovenia, Spain and Switzerland, to more than USD 2.5 a litre in Finland, Ireland, Norway, Sweden and the United Kingdom. A combination of specific and ad valorem excises is normally applied to tobacco products, with cigarettes being taxed more heavily than other products in most countries. Excise

The Danish government repealed their tax on foods high in saturated fat and on soft drinks at the end of 2012. 
duties are usually part of the VAT tax base (so an excise increase leads to an increase in both excise and VAT revenues) with VAT rates on tobacco and alcoholic beverages between 5\% (Japan) and 27\% (Hungary) (OECD 2012). The application of reduced rates of value added and sales taxes are common in the OECD area for commodities like basic foods or water. In the European Union (EU), reduced rates applied to selected foods vary from 3\% (Luxemburg) to 18\% (Hungary) (European Commission 2012).

7. Supra-national regulation by bodies such as the EU or the World Trade Organization (WTO) may limit certain aspects of national policies on commodity taxes (Alemanno and Carreño, 2011). For instance, EU legislation adopted in connection with the establishment of the Internal Market on $1^{\text {st }}$ January 1993 , determines the structure of the taxes to be applied on alcoholic beverages and manufactured tobacco products (e.g. product categories, excise calculation, possible exemptions), and the minimum rates of duty that all Member States have to apply for each product category ${ }^{2}$. In the absence of specific regulation (as is the case with food excises), member states are allowed to introduce and maintain internal taxes, and to establish their modalities, but within the limits of more general EU taxation principles (e.g. prohibiting discrimination across similar products). Although the harmonisation of excise taxes on alcohol and tobacco effectively amounts to an EU taxation policy, the primary competence for tax policy remains with member states, and the initiative for imposing new harmonised taxes (e.g. on foods) is most unlikely to be taken at the EU level, unless the view prevails that such taxes would be strongly justified on health protection grounds.

8. The WTO sets further rules on excise taxation for its member countries. For instance, WTO's General Agreement on Tariffs and Trade (GATT) prevents imported products from being taxed in excess of the like domestic products.

\section{The rationale for the use of commodity taxes in health promotion}

9. The key public health rationale for the use of taxes on health-related commodities lies in their ability to change people's consumption behaviours. As with other attempts to use taxes to prevent some adverse outcome (e.g. environmental taxes), a key issue becomes the proximity of the tax point to the behaviour being targeted. The closer is the tax point to the behaviour, then (other things being equal) the more likely is the tax to have a beneficial impact. Excises introduced for public health purposes illustrate the dilemma clearly. Although for administrative reasons the tax may be levied earlier in the supply chain, the tax point is generally the purchase of the product by a consumer. In the case of tobacco, the harm caused by the product is, to a great extent, independent of the way it is consumed (although the harm will be even greater in an environment which results in secondary smoking). The relationship is less strong with alcohol, because the manner in which alcohol is consumed affects the harm which is caused. This relationship is even looser with diet-related taxes. The harmful effects associated with alcohol and food consumption derive mostly from excessive or inappropriate consumption (e.g. heavy episodic drinking) while taxes obviously hit all consumers, albeit to different degrees. This does not mean that taxation is an inappropriate instrument, but rather that, in addition to the harms discouraged by the tax, the welfare impacts on a broader group of consumers will have to be considered, as further discussed in section 10.

10. From an economic perspective, government intervention to influence individual consumption choices may be justified in limited circumstances. The stronger economic justification is usually offered by the presence of negative externalities from the consumption of a given commodity, of the kind we see, for instance, with passive smoking, or crime and violence resulting from alcohol abuse. The addictive nature

2 For instance, for alcoholic beverages: (a) for spirits, $€ 550$ per hectolitre of pure alcohol, (b) for intermediate products, $€ 45$ per hectolitre of product, (c) for wine and sparkling wine, no minimum rate, (d) for beer, $€ 0.748$ per hectolitre per degree Plato, or $€ 1.87$ per hectolitre per degree alcohol, of finished product. 
of the consumption of commodities like tobacco and alcohol limits the rationality of consumption choices, and so do psychological mechanisms, such as hyperbolic discounting and inconsistent time preferences (Sassi and Hurst, 2008), which behavioural economics research has compellingly brought to the surface in recent years. In the absence of justifications like those mentioned above, the use of taxes tends to be viewed as a paternalistic measure, unduly interfering with individual choice and fair market competition. Governments levying such taxes are sometimes accused to be "profiting" from unhealthy behaviours. Paternalistic or not, fiscal measures are among the options available in the pursuit of public health objectives. "Although economists have little to say on the objectives as such, they can analyse the efficacy of one instrument over another in achieving the objectives" (Cnossen, 2005).

11. Taxes on consumption are typically regressive, unless consumption is concentrated among the wealthiest, which is certainly not the case for most health-related commodities, the consumption of which tends to concentrate among the less well off. Therefore, tax payments will weigh more heavily on the incomes of the most disadvantaged (although the latter will also benefit disproportionately in health terms). Enforcement can be complex and expensive. When prices in a market are kept artificially high by taxation, phenomena like parallel trade and smuggling could flourish, which governments must then regulate or repress. All of the above issues, discussed in sections 5-7 of this paper, are of concern to governments wishing to use taxes as a health promotion tool. 


\section{SECTION II - IMPACTS ON CONSUMPTION AND HEALTH}

\section{How do consumers respond to price changes?}

12. The impact of commodity taxes on consumption is determined by the price elasticity of the demand for such commodities, i.e. by the responsiveness of consumers to price changes, assuming that the levy imposed translates into higher prices at the point of consumption (this latter aspect is discussed in section 5 below). An inelastic demand means that the relative change in the quantity consumers will demand is smaller than the relative change in price. An elastic demand means the opposite ${ }^{3}$. The elasticity of the demand for a commodity determines whether consumers will increase the proportion of their own income they spend on that particular form of consumption (inelastic demand), or decrease it (elastic demand), when a tax increases the price of that commodity.

13. With an inelastic demand, levying a tax on a commodity will likely displace other forms of consumption, because the income available for other forms of consumption will shrink. The concept of cross-price elasticity of demand is used to reflect the sensitivity of other forms of consumption to changes in the price of a given commodity. Depending on the nature of the consumption that is displaced, this displacement effect may strengthen or weaken the ability of the tax to achieve its goals. If the tax is aimed at reducing the consumption of potentially unhealthy commodities whose demand is inelastic, and consumers end up decreasing their consumption of healthier commodities, as well as their consumption of the taxed commodities, the purpose of the tax will be largely defeated. A further problem may arise when a close substitute for the taxed good is available, leading to an elastic demand. Consumers may reduce, even substantially, their consumption of the taxed commodity and replace this with an increased consumption of the substitute commodity. If the latter has similarly negative consequences on consumers' health as the former, the purpose of the tax is again largely defeated.

14. The revenues for the suppliers of a commodity subjected to taxation and for the government will also depend on the price elasticity of demand. Suppliers' revenues will most likely shrink relative to a situation without taxes (assuming a negative price elasticity), but they will shrink more if demand is elastic. Similarly, tax revenues will be smaller with an elastic demand.

\subsection{Changes in the consumption of taxed commodities}

15. The demand for most health-related commodities that are currently taxed or have been considered for possible taxation tends to be inelastic. However, it is easier for people to find substitutes for certain commodities (e.g. specific types of food) than for others (e.g. cigarettes), therefore, the overall impact of a tax will partly depend on whether the tax is suitably designed to cover possible substitute commodities. The existing evidence of the responsiveness of consumers to changes in the prices of healthrelated commodities is summarised in the remainder of this section. consumption. Given that prices are usually inversely related to consumption, own-price elasticity is generally negative, meaning that a price increase leads to a decrease in consumption and vice versa. An elasticity value between 0 and -1 reflects an inelastic demand, while lower negative values reflect an elastic demand. 


\section{Alcoholic beverages}

16. Four recent meta-analyses reported average elasticities for all alcoholic beverages in the region of -0.50 , while elasticities for specific beverages ranged, respectively, from -0.29 to -0.46 for beer, from 0.46 to -0.70 for wine and from -0.54 to -0.80 for spirits (Wagenaar et al., 2009; Forgarty, 2008; Gallet, 2007; Nelson, 2013a), with the lowest estimates for individual beverages resulting from a meta-analysis which corrected for outliers and publication bias (Nelson, 2013a). As in most meta-analyses, the primary studies included are relatively heterogeneous and originate from countries whose patterns of drinking and relative preferences for different types of beverages may not be generalizable to other countries. However, country effects on alcohol price elasticity were found to be largely related to the market shares of different beverages (Fogarty, 2006). The dominant beverage in each country tends to be less responsive to changes in price than the other beverages. Wine demand is more inelastic in wine-producing countries (e.g. France, Italy, Spain and Portugal), where regular wine consumption is common (Leppanen et al., 2001), while beer demand is more inelastic in most Anglo-Saxon countries (Rabinovich et al., 2012).

17. The demand for alcoholic beverages is also influenced by social factors: whereas wine is consumed by higher-skilled workers and less by students, beer and spirits are more often consumed by medium-skilled workers and by the unemployed (Collis et al., 2010). At least two reviews found young drinkers to be responsive to price changes (Babor et al., 2010; Elder et al., 2010), but findings from individual studies are heterogeneous, with several studies suggesting a lesser response by young drinkers, and others suggesting the opposite (e.g. Kuo et al., 2003). A comprehensive meta-analysis concluded that young consumers (age 18-24) have a lower price elasticity than older ones, which may be partly due to young people often consuming less price-sensitive beverages, such as beer (Gallet, 2007). A systematic review found that prices influence drinking participation by young adults, but have a lesser impact on heavy drinking in the same group (Nelson, 2013b). Price changes affect both light and heavy drinkers (Wagenaar et al., 2009), although some studies show that the latter tend to be less responsive than moderate drinkers (e.g. Ayyagari et al., 2013; Nelson 2013b). Estimates for England indicate an average price elasticity of -0.21 for heavy drinkers and -0.47 for moderate drinkers (Meier, 2008). Heavy episodic drinking is highly responsive to alcohol prices. A study in the United States shows that for a $1 \%$ increase in the price of alcohol, the probability of young consumers (aged 14-21) engaging in frequent (more than three times a month) heavy episodic drinking decreases by $2.36 \%$ in the long run, and by $1.29 \%$ in the short run. In addition, an increase in alcohol prices decreases the probability for an individual to become a binge drinker (Keng and Huffman 2010). Heavy episodic drinking by pregnant women younger than 44 was also shown to respond to changes in alcohol prices through taxation, with an elasticity of -2.5 for beer and wine, and -9 for spirits (Zhang, 2010).

\section{Tobacco}

18. Estimates of the price elasticity of the demand for tobacco products vary in a relatively wide range, however, most estimates for cigarettes are between -0.3 and -0.5 , meaning that a $10 \%$ increase in cigarette prices would produce a decrease in demand of 3-5\% (Levy et al., 2004; Chaloupka et al., 2012; Goel et al., 2006; Gallet and List, 2003). Consumers in different countries react differently to price changes, depending on the characteristics of local markets and government policies in place. For instance, a study found a higher elasticity in Canada than in many other countries (-0.72), likely due to higher prices and relatively intense smuggling. After adjusting for the effects of smuggling, estimates were reduced to -0.45 to -0.47 (Gruber et al., 2003).

19. There is evidence of a greater responsiveness to price changes of young consumers and consumers with a poorer socioeconomic background, although evidence of a socioeconomic gradient in price elasticity is not clear for middle- and low-income countries (Levy et al., 2004; Chaloupka et al., 2012). The demand for cigarettes tends to be more price-responsive in the long run than in the short run 
(Gallet and List, 2003, Chaloupka et al., 2012), over which a UK-based study found elasticities of -1.05 and -0.57 , respectively (Czubek and Johal, 2010).

\section{Food and non-alcoholic beverages}

20. Studies undertaken in different countries provide a range of elasticity estimates for foods and non-alcoholic beverages, partly dependent on the definitions and the degrees of aggregation of food categories. Staple foods tend to have a less elastic demand than foods that are easier to substitute. The demand for most foods is inelastic, and more so in higher income countries, as shown in Table 1. The demand for food consumed away from home is more elastic $(-0.81)$ than the demand for food at home (-0.59) (Andreyeva et al., 2010). However, if people are aware that a product was taxed for public health reasons, they may be more likely to change their consumption (Thow et al., 2010).

21. Carbonated soft drinks have recently been viewed as a possible target of taxation, and taxes have been introduced in certain countries (e.g. France and Mexico). Elasticity estimates for soft drinks vary in a relatively broad range, from inelastic to elastic, as shown in Table 1 (Andreyeva et al., 2010; Green et al. 2013; Gallet 2010; Powell et al., 2013). The potential for substitution across beverage categories is high, therefore elasticity estimates may depend on the aggregation of categories for which the effects of price changes are examined (Smith et al., 2010).

22. Low-income consumers and children are the most price-sensitive (Faulkner et al., 2011). The impact of price changes is stronger for consumers in poorer socioeconomic condition, who have a more elastic demand for a range of food products (Green et al., 2013), although a French study found that lowincome households were less sensitive to changes in the prices of fresh vegetables and fruit than highincome households (Allais et al., 2010). On average, low-income adults consume more calories from sugar-sweetened beverages (SSBs) and have a less elastic demand than high-income consumers (-0.95 vs. -1.29), however, the gradient was reversed in children and for low-calorie drinks ( -0.70 for low-income, -0.46 for high-income consumers) in a US study (Lin et al., 2011). 
Table 1. Own price elasticity of the demand for selected foods and non-alcoholic beverages

\begin{tabular}{|c|c|c|c|c|c|}
\hline \multirow[b]{2}{*}{$\begin{array}{c}\text { Food/ beverage } \\
\text { group }\end{array}$} & \multirow{2}{*}{$\begin{array}{l}\text { Systematic reviews } \\
\text { United States }^{1,2}\end{array}$} & \multicolumn{4}{|c|}{ Meta-analyses } \\
\hline & & $\begin{array}{l}\text { Low income } \\
\text { countries }^{3}\end{array}$ & $\begin{array}{l}\text { Middle income } \\
\text { countries }^{3}\end{array}$ & $\begin{array}{l}\text { High income } \\
\text { countries }^{3}\end{array}$ & $\begin{array}{c}\text { Countries at } \\
\text { different level of } \\
\text { income }\end{array}$ \\
\hline Beef & $\begin{array}{c}-\mathbf{0 . 7 5} \\
(-0.29 \text { to }-1.42) 1\end{array}$ & - & - & - & $\begin{array}{c}\mathbf{- 1 . 0 2 5} \\
(-0.944 \text { to }-1.107) \\
\end{array}$ \\
\hline Pork & $\begin{array}{c}-\mathbf{0 . 7 2} \\
(-0.17 \text { to }-1.23) 1 \\
\end{array}$ & - & - & - & $\begin{array}{c}-\mathbf{0 . 9 1 3} \\
(-0.818 \text { to }-1.009)\end{array}$ \\
\hline Poultry & $\begin{array}{c}-\mathbf{0 . 6 8} \\
(-0.16 \text { to }-2.72)^{1}\end{array}$ & - & - & - & $\begin{array}{c}-\mathbf{0 . 7 8 9} \\
(-0.695 \text { to }-0.885)\end{array}$ \\
\hline Lamb & - & - & - & - & $\begin{array}{c}\mathbf{- 1 . 0 2 8} \\
(-0.841 \text { to }-1.216)\end{array}$ \\
\hline Fish & $\begin{array}{c}-\mathbf{0 . 5 0} \\
(-0.05 \text { to }-1.41)^{1}\end{array}$ & $\begin{array}{c}-\mathbf{0 . 8 0} \\
(-0.85 \text { to }-0.74)\end{array}$ & $\begin{array}{c}-\mathbf{0 . 7 3} \\
(-0.79 \text { to }-0.67)\end{array}$ & $\begin{array}{c}-\mathbf{0 . 6 1} \\
(-0.67 \text { to }-0.55)\end{array}$ & $\begin{array}{c}-\mathbf{0 . 9 7 1} \\
(-0.888 \text { to }-1.054)\end{array}$ \\
\hline Meat & - & $\begin{array}{c}-\mathbf{0 . 7 8} \\
(-0.83 \text { to }-0.73)\end{array}$ & $\begin{array}{c}-0.72 \\
(-0.78 \text { to }-0.66)\end{array}$ & $\begin{array}{c}-\mathbf{0 . 6 0} \\
(-0.66 \text { to }-0.54)\end{array}$ & $\begin{array}{c}-\mathbf{0 . 8 8 3} \\
(-0.778 \text { to }-0.989)\end{array}$ \\
\hline Fats/oils & $\begin{array}{c}-\mathbf{0 . 4 8} \\
(-0.14 \text { to }-1.00) 1\end{array}$ & $\begin{array}{c}-\mathbf{0 . 6 0} \\
(-0.65 \text { to }-0.54)\end{array}$ & $\begin{array}{c}-0.54 \\
(-0.60 \text { to }-0.47)\end{array}$ & $\begin{array}{c}-\mathbf{0 . 4 2} \\
(-0.48 \text { to }-0.35)\end{array}$ & - \\
\hline Eggs & $\begin{array}{c}-0.27 \\
(-0.06 \text { to } 1.28) 1\end{array}$ & $\begin{array}{c}-\mathbf{0 . 5 4} \\
(-0.67 \text { to }-0.42) \\
\end{array}$ & $\begin{array}{c}-\mathbf{0 . 4 8} \\
(-0.61 \text { to }-0.35)\end{array}$ & $\begin{array}{c}-0.36 \\
(-0.49 \text { to }-0.23)\end{array}$ & - \\
\hline Diary & $\begin{array}{c}-\mathbf{0 . 6 5} \\
(-0.19 \text { to }-1.16) 1 \\
\end{array}$ & $\begin{array}{c}-\mathbf{0 . 7 8} \\
(-0.84 \text { to }-0.73) \\
\end{array}$ & $\begin{array}{c}-0.72 \\
(-0.78 \text { to }-0.66) \\
\end{array}$ & $\begin{array}{c}-0.60 \\
(-0.66 \text { to }-0.54)\end{array}$ & - \\
\hline Cereals & - & $\begin{array}{c}-\mathbf{0 . 6 1} \\
(-0.66 \text { to }-0.56)\end{array}$ & $\begin{array}{c}-\mathbf{0 . 5 5} \\
(-0.61 \text { to }-0.49)\end{array}$ & $\begin{array}{c}-\mathbf{0 . 4 3} \\
(-0.48 \text { to }-0.36)\end{array}$ & - \\
\hline Sweet/sugars & $\begin{array}{c}-\mathbf{0 . 3 4} \\
(-0.05 \text { to }-1.00)^{1} \\
\end{array}$ & - & - & - & - \\
\hline $\begin{array}{c}\text { SSBs, sweets \& } \\
\text { confectionery }\end{array}$ & - & $\begin{array}{c}-\mathbf{0 . 7 4} \\
(-0.82 \text { to }-0.65) \\
\end{array}$ & $\begin{array}{c}-0.68 \\
(-0.77 \text { to }-0.59) \\
\end{array}$ & $\begin{array}{c}-\mathbf{0 . 5 6} \\
(-0.65 \text { to }-0.48)\end{array}$ & - \\
\hline Fruit & $\begin{array}{c}-0.70 \\
(-0.16 \text { to }-3.02)^{1} \\
-0.49 \\
(-0.26 \text { to }-0.81)^{2}\end{array}$ & \multirow{2}{*}{$\begin{array}{c}-0.72 \\
(-0.77 \text { to }-0.66)\end{array}$} & \multirow{2}{*}{$\begin{array}{c}-0.65 \\
(-0.71 \text { to }-0.59)\end{array}$} & \multirow{2}{*}{$\begin{array}{c}-0.53 \\
(-0.59 \text { to }-0.48)\end{array}$} & - \\
\hline Vegetables & $\begin{array}{c}-\mathbf{0 . 5 8} \\
(-0.21 \text { to }-1.11)^{1} \\
-\mathbf{0 . 4 8} \\
(-0.26 \text { to }-0.72)^{2}\end{array}$ & & & & - \\
\hline Soft drinks & $\begin{array}{c}-\mathbf{- 0 . 7 9} \\
(-0.13 \text { to }-3.18)^{1, a} \\
-\mathbf{0 . 8 6} \\
(-0.41 \text { to }-1.86)^{2, b}\end{array}$ & - & - & - & - \\
\hline $\begin{array}{c}\text { Isotonic, sport } \\
\text { drinks }\end{array}$ & $\begin{array}{c}-\mathbf{- 2 . 4 4} \\
(-1.01 \text { to }-3.87)^{2} \\
\end{array}$ & - & - & - & - \\
\hline Juice & $\begin{array}{c}-0.76 \\
(-0.33 \text { to }-1.77)^{1}\end{array}$ & - & - & - & - \\
\hline Milk & $\begin{array}{c}-\mathbf{0 . 5 9} \\
(-0.02 \text { to }-1.68)^{1}\end{array}$ & - & - & - & - \\
\hline
\end{tabular}

${ }^{1}$ Andreyeva et al., 2010. Systematic review (mean price elasticity estimates, and ranges in parentheses).

${ }^{2}$ Powell et al., 2013. Systematic review (mean price elasticity estimates, and ranges in parentheses).

${ }^{3}$ Green et al. 2013 Meta-regression (predicted price elasticity estimates, and $95 \%$ confidence intervals in parentheses)

${ }^{4}$ Gallet, 2010 Meta-regression (predicted price elasticity estimates, and $95 \%$ confidence intervals in parentheses - full sample, heterogeneous effects estimates)

${ }^{a}$ Different definitions of soft drinks are used in different studies. Fruit juices are not included

${ }^{b}$ Soft drinks include both regular and diet version of soft drinks. 


\subsection{Changes in the consumption of other commodities}

23. When the price of a commodity changes, consumers often adjust to the new price by changing not only their consumption of the commodity in question, but also their consumption of other commodities that are viewed as substitutes or complements of the first. The concept of cross-price elasticity of demand is used precisely to reflect the responsiveness of the demand for one commodity to a change in the price of another commodity. The cross-price elasticity is positive for commodities that may be substitutes for each other, and if the elasticity value is greater than one the commodities are regarded as close substitutes. Conversely, a negative cross-price elasticity is typically observed for commodities that are complementary in consumption, and the strength of the relationship is reflected, again, in the absolute value of the parameter.

\section{Tobacco and alcoholic beverages}

24. Ready-rolled cigarettes are the most common tobacco product used in most countries, but substitute products do exist, including roll-your-own cigarettes, smokeless tobacco (e.g. snuff and chewing tobacco), and electronic cigarettes. In the United States, for instance, different tax rates are applied to cigarettes and smokeless tobacco, and the cross-price elasticity of smokeless tobacco, relative to changes in the taxation of cigarettes, is around 0.4 (Ohsfeldt and Boyle, 1994).

25. Existing studies show a complex relationship between tobacco and alcohol consumption (Goel, 2006). Smokers respond to changes in alcohol prices by changing consumption in the opposite direction (complementary commodities), while drinkers respond less (or not at all) to changes in cigarette prices. A possible explanation may be that smokers smoke more in social circumstances, when they also drink alcohol (Koksal and Wohlgenant, 2011; Pierani and Tiezzi, 2005). A study found alcohol to be a substitute for cigarettes when the price of the latter changed (cross-price elasticity of 0.5 ), but found a complementary relationship when the price of beer changed (-0.14) (Decker and Schwartz, 2000). The asymmetry in the cross-price elasticities of tobacco and alcohol products suggests that, in order to maximise public revenues from the taxation of the two commodities, taxes on alcohol should be raised more than those on tobacco (Pierani and Tiezzi, 2005).

26. A study based in South Australia showed that cigarette smoking decreased when the price of cannabis increased (cross-price elasticity -0.13 ), but cannabis consumption remained virtually unchanged following variations in cigarette prices. On the other hand, cannabis was a substitute for alcohol when the price of the latter changed (0.42), but alcohol consumption was not sensitive to cannabis price (Cameron et al., 2001). Alcohol and drugs are often found to be substitutes. However, a study of young consumers (aged 14-21) in the United States found that cannabis use decreased when beer prices rose (Pacula, 1998). Studies of polysubstance misusers also found cocaine consumption to decrease in response to alcohol price increases, but the same was not true for other drugs, and alcohol was a substitute for cocaine when the price of the latter changed (Sumnall et al., 2004; Petry, 2001).

\section{Food and non-alcoholic beverages}

27. A complementary relationship was found between regular soft drinks and low-calorie soft drinks, except fruit drinks and juices, isotonic drinks and milk (e.g. -0.86, Dharmasena and Capps, 2012; -0.46, Smith et al., 2010, for an increase in the price of regular soft drinks, and marginally lower values for an increase in the price of low-calorie drinks), although the evidence is not yet conclusive. Lin et al. (2011) identify this fact as a contributor to the strong industry opposition to proposals for taxes on non-alcoholic beverages. Substitution generally takes place within, rather than across, beverage categories, i.e. between caloric sweetened beverages, or between low-calorie beverages (Bonnet and Réquillart, 2011; Bonnet and Réquillart, 2012). SSBs are also close substitutes for fruit juices (1.03, Dharmasena and Capps, 2012), and 
fruit and vegetable pure juices are substitutes for caloric sweetened beverages such as sodas, fruit drinks, sport and energy drinks (0.56, Smith et al., 2010). A study of the impact of a tax on SSBs in the United States concluded that no significant substitutions to other sugary foods and beverages would take place, while a parallel reduction in the consumption of complementary caloric products would further reduce energy intake (Finkelstein et al., 2013).

28. A study of the impact of taxes on non-alcoholic beverages in the United States found a substitution effect between soft drinks (excluding juices) and whole milk by children and adolescents, which made the effect of the taxes virtually neutral on calorie consumption in this age group (Fletcher et al., 2010). SSBs are also weak substitutes for low-fat milk (1\% fat and skim milk) with a cross-price elasticity of 0.24 (Dharmasena and Capps, 2012).

29. Studies have explored the cross-price elasticity of the demand for low-fat milk relative to changes in the price of whole milk. Consumers are more likely to switch to reduced- or low-fat milk than skim milk when the price of whole milk increases; indeed, skim and whole milk are weak substitutes (Andreyeva et al., 2010; Smith et al., 2010). Another study found that cross-price elasticities between all dairy products are sometimes positive, sometimes negative, but always very small in absolute value (generally below 0.15), suggesting that the demands for those products are only weakly related (Chouinard et al., 2007).

30. Finally, healthier foods (fruit and vegetables, poultry, fresh fish) and less healthy foods (sugar and sweeteners, butter, margarine, pork, beef and veal) are only weak substitutes, with cross-price elasticity estimates in the region of 0.01 (Luo and Huang, 2010). Taxing foods may have unexpected effects on health if cross-price elasticities are not properly considered. For instance, two different UKbased studies showed that taxing exclusively the principal sources of dietary saturated fat may not improve health, as the benefits may be offset by an increase in salt consumption in the presence of substitute foods (Nnoaham et al., 2009; Mytton et al., 2007). Similarly, a study of the effects of taxes on SSBs predicted a potential increases in sodium and fat intake (Zhen et al., 2013).

\section{To what extent do fiscal measures affect prices?}

31. For taxes on health-related commodities to have an effect on the consumption of those commodities, taxes must raise consumer prices. If, on the other hand, taxes were completely absorbed at some stage in the supply chain, they would end up reducing profits at that stage (e.g. manufacturing). Consumer demand would not be affected, but market equilibrium would likely change anyway. The degree to which taxes translate into changes in consumer prices is often called "pass-through". In the case of health-related commodities, the demand for which is mostly inelastic, taxes are likely to be passed on to consumers, possibly even with a price increase exceeding the amount of the tax. In practice, the degree of pass-through depends on a number of factors and circumstances, and is not always predictable.

32. Key drivers of pass-through include strategic behaviours of manufacturers and retailers (production and marketing strategies, particularly for multi-product firms), production costs, the market structure and relative supply and demand elasticities (Andreyeva et al., 2011; Bonnet and Réquillart, 2012).

33. In oligopolistic industries taxes can lead to price increases greater than their nominal value (Anderson et al. 2001; Keeler et al. 1996; Sung et al 1994), a phenomenon referred to as overshifting. Keeler et al. (1996) estimated that a one-cent increase in cigarette taxes would increase retail prices by 1.1 cents, on average, in the United States. Evidence of overshifting was also found in Denmark for excise taxes on soft drinks (Bergman and Hansen, 2013). Studies comparing different forms of taxation found that specific excise taxes tend to be overshifted, while ad valorem taxes are undershifted. In France, an overshift of $7 \%$ to $33 \%$ was predicted for a specific duty on soft drinks, while an equivalent ad valorem tax 
would be undershifted by $10 \%$ to $40 \%$ (Bonnet and Réquillart, 2012). The same was shown for a possible tax on saturated fat in the UK, leading to the conclusion that a specific rate excise tax would reduce saturated fat purchases more, and generate more substitution, than an ad valorem tax (Griffith et al., 2010).

34. Firm profits are less affected by specific than ad valorem taxes. But the latter have a larger impact on government revenues. Multi-product firms can use portfolio pricing strategies to optimise revenues by accounting for likely substitutions across products (Griffith et al., 2010; Bonnet and Réquillart, 2012).

\section{Tobacco}

35. Tobacco companies have used pricing policies to respond to tax hikes and other tobacco control efforts by governments (Chaloupka et al., 2002). Smokers bear approximately 52\% of cigarette excise taxes in the United States. Estimates of tax pass-through vary from 0.39 for premium cigarettes sold by the carton to 0.64 for discount cigarettes sold by the pack. Pass-through is greater for price-inelastic brands and smaller when avoidance of State cigarettes taxes by consumers is easier. For instance, a low passthrough is observed near the borders with low-tax jurisdictions, and for products like cigarettes sold by the carton, for which cross-border avoidance is greatest (Chiou and Muehlegger, 2010). When considering the prices effectively paid by consumers, after accounting for strategic behaviours such as trading down (e.g. brand switching) or cross-border shopping, there is some evidence that light and occasional smokers end up facing slightly larger price increases following tax hikes (DeCicca et al., 2010).

\section{Alcoholic beverages}

36. Large differences in tax pass-through across different types of alcoholic beverages and brands reflect different demand elasticities for different products. Taxes on beer are more than fully passed on to consumers when there is a tax hike (pass-through of 1.34) while there is undershifting when taxes are cut (0.27) (Bergman and Hansen, 2013). For both on-premise and off-premise sales of many brands of beer in the United States, as well as for off-premise spirit sales, average pass-through rates were found to be around 2. Higher rates, close to 4 , were found for on-premise wine and spirit sales. Beer excise duties are undershifted in Ireland ( 0.5 off-trade, 0 on-trade) and Finland ( 0.8 off-trade, 0.7 on trade), and overshifted in off-trade sales in Latvia (1.9) and Slovenia (2.5) (Rabinovich et al. 2012). For spirits, excise duties are undershifted in on-trade sales in Finland (0.8) and Ireland (0.1), but overshifted in off-trade sales in Finland (1.4) and Latvia (1.3), while they are undershifted in off-trade sales in Ireland (0.7) and Slovenia (0.7) (Rabinovich et al. 2012). Establishments that charged higher prices tended to pass on less of the tax hike to their customers (Kenkel, 2005). Generally, alcohol taxes are more than fully passed through to prices.

\section{Food and non-alcoholic beverages}

37. Usually food and beverage manufacturers and retailers pass taxes onto consumers in excess of the amount of the tax (Miao et al., 2011; Andreyeva et al., 2011). Differences in tax pass-through across different types of retailers have been shown after the introduction of a fat tax in Denmark (Jensen and Smed 2013).Tax pass-through for soft drinks is above two when taxes are increased and below one when taxes are reduced (Bergman and Hansen, 2013). A study estimating the impact of an early version of a soft-drink tax adopted in France in 2012, hitting only SSBs (while the tax was eventually applied to all soft drinks), predicted an average pass-through of 1.22, larger for national, compared with "private label", brands. Manufacturers were thus predicted to overshift the tax, while the price of low-calorie beverages was estimated to remain relatively stable, with a decrease of less than $2 \%$ (Bonnet and Réquillart, 2013). A post-hoc study after the introduction of the French soda tax in January 2012, focusing on purchases of beverages previously ordered on the Internet, estimated that consumer prices increased gradually. By 
May 2012, the tax was more than fully shifted to soda prices while about $85 \%$ and $60 \%$ of the tax was passed through to consumers for flavoured waters and fruit drinks, respectively, but with a high degree of heterogeneity across retailers and brands (Berardi et al. 2012).

\section{Can taxes improve health?}

38. The question of whether commodity taxes will eventually have an impact on health outcomes such as disease incidence and longevity is virtually impossible to answer through direct empirical observation. This is because of the time lag that often occurs between the effects of the tax on consumption and the health consequences of the change in consumption, and because of the difficulties involved in isolating the effect of the tax from those of a multitude of concurrent factors. For the above reasons, we have to rely on models in assessing the health impacts of taxes, and several studies adopting different modelling approaches are currently available to shed light on this key question.

\section{Tobacco}

39. The World Bank conservatively estimated that a sustained real price increase of $10 \%$ for tobacco products would lead to 40 million people worldwide quitting smoking and to deterring many more from taking up the habit. This price increase alone would avoid 10 million premature deaths, or $3 \%$ of all tobacco-related deaths. Four million of the premature deaths avoided would be in East Asia and the Pacific region (Jha and Chaloupka, 1999). A large number of model-based studies have produced similar findings on the health effects of tobacco taxes. A dynamic computer simulation study showed that a price increase of at least $20 \%$ in California may reduce smoking prevalence from $17 \%$ to $11.6 \%$, with a gain of almost 16 million QALYs over 75 years (Ahmad, 2005). A study based on data from 1954 to 2005 found a longrun relationship between respiratory cancer mortality and cigarette taxes, due to higher prices leading people to quitting smoking (Liu et al., 2011).

\section{Alcoholic beverages}

40. Some of the health effects of reduced alcohol consumption through taxes occur in the short term and can be estimated reasonably accurately. For instance, it was estimated that a $10 \%$ increase in alcohol prices would reduce traffic fatalities by $5.8 \%$ ranging from $6.9 \%$, for weekend night fatalities, to $3.9 \%$ for other times (Young, 2006). A recent meta-analysis showed that alcohol taxes and pricing policies significantly affect alcohol-related disease and injury rates (Wagenaar et al., 2010). In particular, doubling tax rates would decrease alcohol-related mortality by an average of $35 \%$. For the same increase in taxation, traffic-crash deaths would decrease by $11 \%$, sexually transmitted disease cases by $6 \%$, violence and crime episodes by $2 \%$ and $1.4 \%$, respectively. Several studies provide evidence of the impact of taxes on longerterm health outcomes. The Dynamo-HIA model was used to estimate the potential impact of tax increases in EU countries over a 10 year period (Lhachimi et al., 2012), showing that raising prices to the levels observed in Finland would lead to major health gains. Similar results were reached using the ACEPrevention modelling approach (Cobiac et al., 2009), the Dutch National Institute for Public Health and the Environment's CDM model (van den Berg et al., 2008; Tariq et al., 2009), the Sheffield Alcohol Policy Model (Meier et al., 2010; Purshouse et al., 2010), and OECD's CDP-Alcohol policy model.

\section{Food and non-alcoholic beverages}

41. The association between changes in food prices and population health is less clear-cut. A review of studies of the impact of prices on weight and obesity found limited evidence that small price changes, through taxation or subsidies, would produce sufficient changes in consumption to generate health benefits, but found larger effects for people with low socioeconomic status and for those at risk of becoming overweight or obese (Powell and Chaloupka, 2009). However, a study of people aged over 50 in the United 
States concluded that only modest changes in body weight can be expected in the short term, while a permanent reduction in price per calorie of $10 \%$ would generate a 1.9 body mass index reduction in the long term (Goldman et al., 2009). A further US study produced estimates of the impact on people's weight of a 0.5 to 1 cent per ounce tax on SSBs, using different demand models (Finkelstein et al., 2013; Zhen et al., 2013). The weight reduction was modest as an individual average (well below $1 \mathrm{~kg}$, after one year), but this would likely translate into a non-negligible reduction in the proportion of people who are overweight or obese in the population. The average weight loss was estimated to approximately double at 10 years, and was estimated to be more than twice as large for low-income as for high-income adults. A recent English study shows similar results. The introduction of a $20 \%$ tax on SSBs in the United Kingdom would reduce the number of obese and overweight adults, by $1.3 \%$ and $0.9 \%$ respectively with likely greater effects in young people (16-29 years) and people of higher socio-economic status (Briggs et al. 2013).

42. On the other hand, a recent review of model-based studies concluded that taxes on soft drinks and foods high in fat, possibly combined with subsidies on fruit and vegetables, do have the potential for generating meaningful health gains and reduce health disparities (Eyles et al., 2012). A Danish study found that reduced VAT rates on fruit and vegetables and an increased taxation of fats and sugar would cut cardiovascular diseases and nutrition-related cancers in the adult population (Holm et al. 2013). Finally, two natural experiments were conducted in the United States. One found that States without a tax on soft drinks or snack foods were over 4 times as likely as States with either of those taxes to have experienced a relative increase in obesity rates in the top quartile, while States that repealed an existing tax were over 13 times as likely, although these differences were not statistically significant (Kim and Kawachi, 2006). On the other hand, a second study found that a $1 \%$ increase in taxes on soda vending machines was associated with a negligible reduction in BMI among adolescents at risk of overweight (Powell et al., 2009).

43. Additional health benefits may indirectly derive from the role possibly played by taxes as incentives to product reformulation. For instance, in 2012, many beer producers in the United Kingdom decreased the alcohol content of their brands sold in the UK by $0.2 \%$ to avoid an increase in duties (Moylan, 2012). 


\section{SECTION III - FURTHER IMPACTS}

\section{The administrative costs of commodity taxes}

44. Relatively few empirical studies have estimated the size of tax operating costs, which include costs borne by the public administration imposing the tax for the collection of revenues and enforcement of compliance (administrative costs) and costs borne by taxpayers, individuals and organisations, to comply with the requirements of the tax (compliance costs). Among these studies, even fewer have focused on administrative costs, partly because countries tend to assess these costs in aggregate, for all types of taxes. Empirical studies tend to provide estimates of operating costs as a proportion of total tax revenues, as some components of the former indeed vary with revenues. However, operating costs are determined by a broader range of factors (associated with the nature of the tax base or with characteristics of the tax) which makes it difficult to generalise existing estimates to new taxes or settings. An extensive review of over 60 studies of the operating costs associated with taxation, published and unpublished, undertaken in the period 1980-2003 concluded that "studies that do address administrative costs suggest that they rarely exceed $1 \%$ of the revenue yield, and more usually come in well below 1\%" (Evans, 2003). In the UK, compliance costs for all excise duties were estimated at $0.1 \%$ of the revenue yield in 2011(HM Revenue \& Customs, 2013) and figures from 2005 show that $78 \%$ of these costs were borne by businesses with more than 250 employees (KPMG LLP, 2006). Another UK study estimated government-borne administrative costs at around $0.2 \%$ of revenue yields, slightly above compliance costs (Sandford et al., 1989). In its proposal for the 2011 Fat Tax Act ${ }^{4}$, the Danish Ministry of Taxation estimated the administrative costs for the public sector as 2.9 million DKK initial one-time costs, plus ongoing operating expenses of about 6 million DKK a year (around $0.5 \%$ of the revenues collected from the fat tax). Estimates for the private sector included reorganisation costs of around 161 million DKK, as well as on-going compliance costs of approximately 35 million DKK.

\section{Tax revenues and the earmarking debate}

45. The revenues generated by taxes on health-related commodities can be substantial in value, and represent a non-trivial proportion of overall tax revenues. Tobacco taxes alone account for $1 \%$ to $10 \%$ of tax revenues in countries at different levels of income, and so do alcohol taxes. Excise taxes levied on tobacco and alcohol products accounted for a stable proportion of total tax revenues between 2000 and 2010 in Germany (2.5\%), for a slightly increasing share in Hungary (3.2\% to 3.4\%), and for a decreasing share in Japan (3\% to $2.6 \%$ ), Finland (2.9\% to $2.5 \%$ ) and Argentina (3.2\% to $1.5 \%$, due to a much steeper increase in total revenues than excise revenues) (source: OECD.Stat). A UK study estimated that a $1 \%$ increase in specific excise duties on tobacco would generate incremental tax revenues of 25 million GBP in the first year and 20 million GBP in years 2 and 3 (Czubek and Johal, 2010), corresponding to $0.3 \%$ and $0.2 \%$ increases, respectively, over current levels. Few countries currently apply excise taxes on food and non-alcoholic beverages, but many do apply value-added and sales taxes, which account for substantial revenues. The revenues collected from the Danish tax on saturated fat were 1,223 million DKK in 2012 and accounted for around $0.14 \%$ of total tax revenues. Fat tax revenues in 2012 were higher than revenues

\footnotetext{
$4 \quad$ Available at: http://ec.europa.eu/enterprise/tris/pisa/app/search/index.cfm?fuseaction=getdraft\&inum=1627030, accessed December 2013.
} 
collected from taxes on beer (1,037 million DKK) or spirits (1,072 million DKK), but lower then revenues from taxes on wine $(1,513 \text { million DKK })^{5}$.

46. Earmarked tax revenues may contribute to funding public health programmes, or limiting the negative impacts of commodity taxes (e.g. their regressive effects). Alternatively, revenues can contribute more broadly to health or social security spending, as in the cases of the recent tax on soft drinks in France and that on selected processed foods in Hungary (Holt, 2011). Examples of earmarking exist in many countries. For instance, the Australian state of Victoria was the first jurisdiction to establish a health promotion agency funded by tobacco taxes, and several US states (California, Massachusetts, Arizona, and Oregon) decided to use part of tobacco tax revenues for tobacco-related education, counter-advertising, and other tobacco-control activities (Chaloupka et al., 2000). In Argentina, tobacco tax earmarking is used to finance health and social programs (WHO, 2010; WHO, 2012). Alcohol revenues are committed to alcohol education and prevention programs in New Jersey, Ohio, Texas (Patterson and Brittain, 2003).

47. However, earmarking may generate problems, as well as opportunities. Many public finance economists have long opposed earmarked taxes because they may limit flexibility in budgetary processes, thus preventing an optimal allocation of resources (Michael, 2012). However, this argument is weakened in the case of earmarking commodity taxes to fund the health sector, because the revenues involved would cover a relatively small proportion of the health sector budget (Heady, 2013). Others have argued that earmarking to fund health promotion and disease prevention is consistent with the "benefit principle" of taxation and can reduce the loss of producer and consumer surplus from the taxes (Hu et al., 1998).

\section{Financial impact on consumers}

48. Commodity taxes are generally (but not always) regressive, and taxes on health-related commodities are no exception, as lower-income households spend larger proportions of their incomes on most of the commodities concerned. In particular, Figure 1 shows household expenditures on food (consumed at home and away from home), alcoholic beverages, and tobacco, by income quintile, as a proportion of average income in each quintile, in the United Kingdom and in the United States. Those with lower incomes spend more, in proportion, than those with higher incomes on all of the above items, even though expenditure on most of the items increases with income, in absolute value. 
Figure 1. Household expenditure on health-related commodities, UK and US

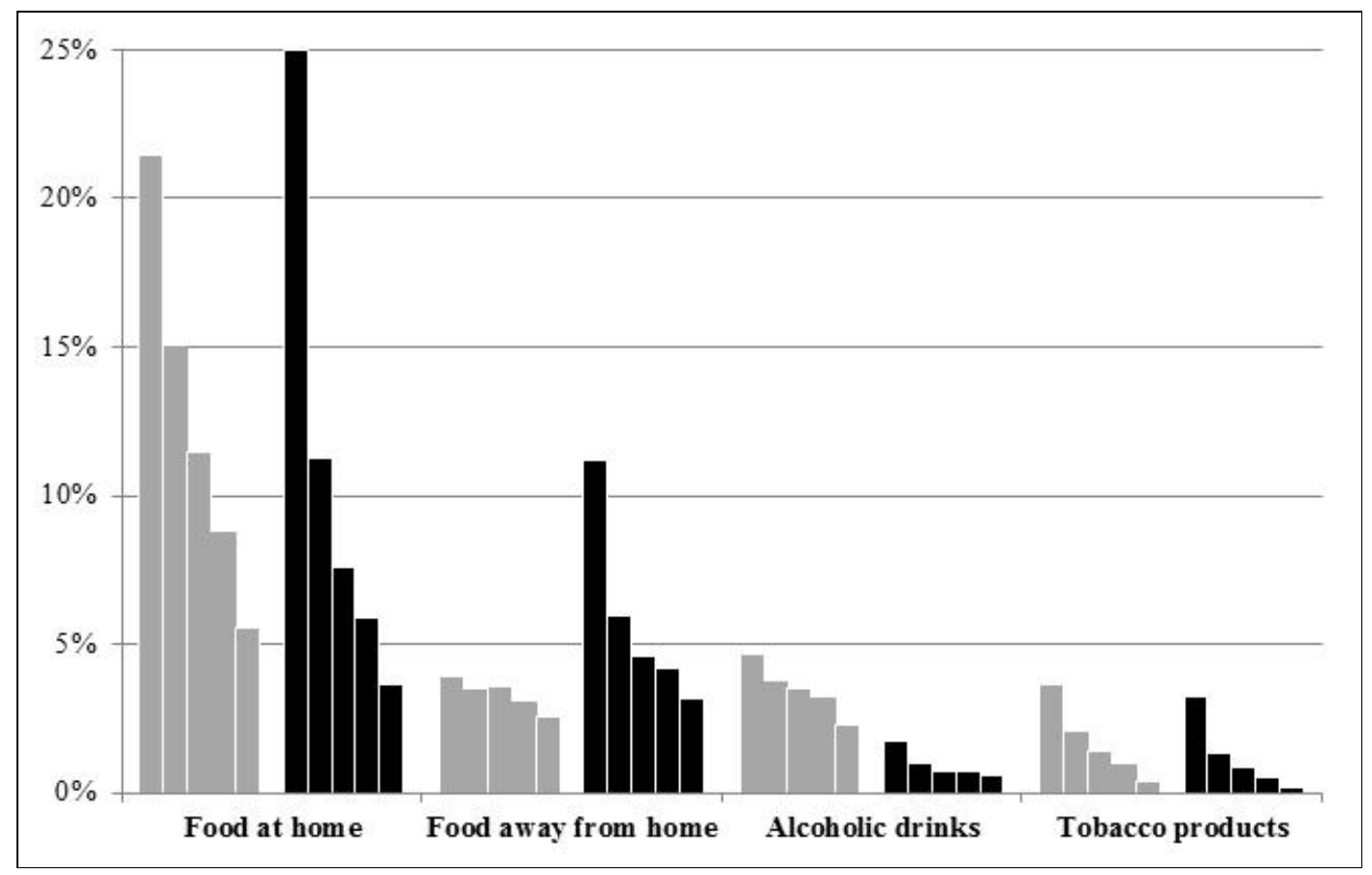

Note: United Kingdom: light bars; United States: dark bars. Groups of bars reflect income quintiles, in ascending order (bottom to top income quintile). Expenditure presented as a proportion of average income in each quintile.

49. To the extent that taxes are proportional to expenditures on the relevant commodities, Figure 1 also reflects an increased actual or potential burden of taxation on food, alcoholic beverages, and tobacco products in lower income groups. Estimates for the United Kingdom indicate that expenditures on alcohol duties by households in the bottom income quintile was $1.6 \%$ of disposable income in 2009-10, while it was $0.9 \%$ for households in the top income quintile. The difference was substantially larger for tobacco duties, with corresponding figures of $3 \%$ and $0.3 \%$, respectively (ONS, 2011). The potential burden of a fat tax in the United Kingdom was estimated to be $0.7 \%$ of the incomes of the poorest consumers, and $0.1 \%$ of those of the richest consumers (Leicester and Windmeijer, 2004). In the United States, a $10 \%$ fat tax on dairy products would weigh 10 times as much on households with an income of $\$ 20,000$, than on those with an income of $\$ 100,000(0.24 \%$ vs. $0.024 \%)$ (Chouinard et al., 2007). A 0.5 cent per ounce tax on SSBs in the United States would mean tax payments of 19 and 23 USD per year, respectively, for households with incomes above and below $185 \%$ of the 2006 federal poverty line, respectively (Zhen et al., 2013), with a tax burden, measured as a proportion of income, several times larger for low income households, which amounts to an extra $\$ 4$ in absolute terms.

50. However, incremental rate changes for existing taxes are not always regressive, because lower income consumers tend to be more responsive to price hikes (see section 4.1), to the point that, in certain circumstances, the latter may have their tax burden increased less than high-income consumers (Chaloupka et al., 2012, Gospodinov and Irvine, 2009, Kotakorpi, 2008). A second factor that must be considered when assessing the potentially regressive effects of taxes on health-related commodities is the distribution of the health benefits likely generated by these taxes, which tends to favour the less well off, who experience a higher incidence and prevalence of conditions commonly linked with the consumption of such commodities (e.g. Sassi et al., 2008, on the potential impacts of food taxes and subsidies in a range of OECD countries). Finally, redistribution measures can be put in place alongside commodity taxes to support the incomes of the consumers who bear the largest tax burden. Redistribution may not only happen 
through transfers, but also through targeted in-kind programmes (e.g. nutrition education programmes aimed at low-income consumers, see Zhen et al., 2011).

\section{Impacts on social welfare and the broader economy}

51. Commodity taxes have a potentially negative impact on social welfare. However, in the case of health-related commodities the impact is unlikely to be negative. In particular, when commodity taxes are charged, consumers who were willing to pay more for the commodity than the price set by the market before the tax, will lose some of their gain (consumer surplus). Some consumers will be priced out of the market, and they will miss the opportunity to enjoy the taxed commodity altogether. Similarly, on the supply side, producers originally willing to provide the commodity for less than the market price will see their gains (surplus) reduced. Others will be put off and exit the market. The size of the loss experienced by consumers and producers exceeding the amount of tax revenues (deadweight loss) depends critically on the slopes of the demand and supply curves, hence on price elasticities (Wang, 2011). The taxation of commodities with a more elastic demand tends to generate a larger welfare loss, which suggests the desirability of a more incisive taxation of commodities with a less elastic demand (Ramsey, 1927). However, the latter include basic and essential commodities, therefore the regressive effects of the tax would be increased, with a clear equity-efficiency trade-off. In addition, Ramsey's principles apply in a world in which only indirect taxes are used, while modern optimal taxation theory accounting for interactions between different types of taxes suggests that indirect taxes should target equally all final consumption goods (Mankiw et al., 2009).

52. The term "producers" used in the previous paragraph encompasses a wide range of actors in the market for health-related commodities, ranging from primary agricultural producers (e.g. crop growers and animal farmers), to manufacturers, retailers, bars and restaurants, but also including collateral industries such as advertising, broadcasting, entertainment, just to mention a few examples. Profit and job losses can be experienced at any stage of the supply chain, when commodity taxes are imposed or increased. However, those losses are likely to be modest and short lived, as diversified businesses will pursue product portfolio strategies to minimise the impacts of taxes, and resources will be invested in alternative businesses when those targeted by taxation are no longer viable (see, for instance, Chaloupka et al., 2012; Jha and Chaloupka, 2000; Schmitt et al., 2007; Huang and Chaloupka, 2011, on the impacts of tobacco taxes).

53. The losses incurred by consumers and producers are partly offset by gains associated with alternative forms of consumption and production in which the former may engage and, most importantly, by benefits arising from the government's use of the tax revenues. A study of taxes on solid fats and added sugars found that welfare losses are overestimated when within-group substitutions are neglected. In particular, while a fat tax would appear to be more efficient than a tax on added sugars, this conclusion is reversed when accounting for substitutions. However, a fat tax would raise larger revenues, therefore the deadweight loss per unit of revenue would be smaller for a fat tax (2.25 cents per dollar of revenue) than for a sugar tax (5.75 cents per dollar) (Miao et al. 2013). Okrent and Alston (2012) assessed a range of food taxation options, and estimated that a tax on calories would generate a smaller deadweight loss than taxes on fat, sugar, or all foods. With any of the types of taxation considered in the study, the size of the welfare loss was significantly smaller than the reductions in public health care expenditure produced by the taxes, leading, for instance, to a net social gain of $\$ 10$ per adult with a 1.65 US cent tax per 1,000 calories. Zhen et al. (2013) estimated that a 0.5 US cent per ounce increase in SSB prices would generate a welfare loss of about 27 USD per low-income household and 22 USD per high-income household per year, due to a larger consumption by the former, which may reinforce the regressive nature of taxes on SSBs.

54. A study of alcohol taxation in Australia estimated tax revenues of 7,426 million AUD in the financial year 2007-08, and a deadweight loss of 612 million AUD in the same year (Byrnes et al., 2012). 
A study of the welfare impacts of tobacco taxation in the United States found that a tax increase raising the price of a pack of cigarette by 1 cent in 1990 ( $0.8 \%$ of the retail price), would generate revenues of around 274 million USD and a deadweight loss of around 105 million USD in one year (Barnett et al.1995). Another study, counting health benefits accruing to consumers not fully informed about the health consequences of smoking as a welfare gain, showed that if only $2.2 \%$ of the population were not fully informed, the corresponding welfare gain would offset the deadweight loss caused by a $20 \%$ increase on tobacco taxation (Peck et al., 2000).

55. However, in the case of taxes on health-related commodities, even the residual loss is likely to be offset, because those taxes tend to compensate for market failures that prevent market exchanges from maximising social welfare. Probably the most compelling example of such failures is negative externalities, which typically prompt the use of corrective taxes. However, many commodities produce externalities, and the mere presence of modest external effects is not sufficient to justify the use of commodity taxes (Frey, 2005). Important externalities exist in the consumption of both alcohol (e.g. crime and anti-social behaviour) and tobacco products (e.g. effects of passive smoking), while their existence is less clear-cut in the case of food and non-alcoholic beverages (Sassi, 2010). But, failures in the markets for health-related commodities that may lead to a higher than socially desirable consumption are not limited to externalities. They may include, for instance, information failures, failures of rationality, such as inconsistent time preferences, addictive and habitual consumption. Estimating the welfare impacts of market failures may be very difficult, but whenever taxes are used, efficient taxation options must be sought in order to ensure socially desirable outcomes.

\section{Tax avoidance and illicit trade}

56. Commodity taxes inevitably generate tax avoidance behaviours, such as cross-border trade within legal limits, as well as illegal phenomena like smuggling and illicit trade (e.g. of informally produced or counterfeit commodities). These phenomena thrive on the wide differences in taxation systems and rates across and within countries. They deprive governments of tax revenues and reinforce criminal organizations and corruption, in addition to exposing the population to health threats when the commodities illegally traded are produced in ways that escape statutory public health controls. Crossborder and illicit trade are major phenomena in some countries, at all levels of income, especially for alcohol and tobacco products. In particular, WHO regularly estimates the size of unrecorded alcohol consumption (including both cross-border and illicit trade), and their data show that this varies widely as a proportion of total estimated consumption in OECD countries (e.g. 1\% in Australia and 35\% in Sweden), as well as in lower income countries (e.g. $20 \%$ in Nigeria, and $72 \%$ in Vietnam).

57. Cross-border trade is a relatively important phenomenon in certain countries and regions within countries, for all of the health-related commodities discussed in this paper. For instance, the introduction of a single market for alcohol in the European Union in 2003 resulted in a tax competition between member countries (Lockwood and Migali, 2008). Finland decreased its alcohol taxes by one third following the accession of neighbouring Estonia in the EU, where alcohol could be bought at substantially lower prices (Anderson et al., 2009). This resulted in increased consumption and alcohol-related deaths (Koski et al., 2007), which led Finland to raise taxes again in 2008. However, the same effects were not observed in Denmark and southern Sweden, despite the adoption of similar measures (i.e. abolition of stringent quotas and reduction of high tax rates on alcohol) in the same time period (Mäkelä et al. 2008). Alcohol and tobacco are considerably more expensive in Norway than in Sweden, due to a higher taxation in Norway.

58. Despite a strict regulation of cross-border shopping, Norwegian stores located near the border report lower revenues from tobacco and alcohol sales than stores elsewhere, whilst consumers living in the same area report no lower expenditures for the same commodities, suggesting that they bear a lower tax burden than other Norwegian consumers (Beatty et al., 2009). However, a Danish study found that tax 
hikes and cuts are passed through to similar degrees in areas at different distances from the German border, despite lower price levels in Germany that may incentivise cross-border trade (Bergman and Hansen, 2013).

59. Cross-border trade affects also food purchases. A study of border counties in West Virginia estimated that the introduction of a $6 \%$ sales tax on food in 1990 led to an $8 \%$ fall in food sales (Tosun and Skidmore, 2007). A similar claim was made in Denmark, after the introduction of a tax on foods high in fat in 2011, which the government decided to repeal only one year later, but it was not substantiated by rigorous empirical evidence.

60. Smuggling and illicit trade are more complex phenomena, determined by a variety of factors, including, but are not limited to, tax differentials between and within countries. A higher incidence of crime and corruption, as well as weaker law-enforcement, are among other potential determinants. The share of illicit trade in the global cigarette market is estimated at $9 \%-11 \%$, relatively stable since 2000 , even if some countries have successfully reduced penetration into their markets (e.g., UK) (Eriksen et al., 2012). The size of the phenomenon varies greatly between countries at all levels of income, but it tends to be larger in low- and middle-income countries than in high-income countries (Joossens et al., 2009). Illicit production and trade of alcoholic beverages also vary widely across countries and tend to be larger in lower-income countries, as shown in Figure 2. Estimates for the United Kingdom suggest a tax revenue loss for illicit alcohol trade close to 1.2 billion GBP (corresponding to an illicit market share of 5\% for spirits and $10 \%$ for beer). The losses for tobacco products were estimated to be close to 1.9 billion GBP (with an illicit market share of $9 \%$ for cigarettes and 38\% for hand rolled tobacco).

61. However, the real question in the context of this paper is whether changes in taxation may have an impact on smuggling and illicit trade volumes, which is very difficult to ascertain, given a virtually complete lack of data. Some, limited, evidence from Eurobarometer survey questions suggests that a higher proportion of respondents had seen tobacco products which they believed were smuggled, during the previous 12 months, in countries with lower taxation rates (e.g. Estonia, 36\%) than in those with higher rates (e.g. Norway, 6\%), which suggests that other factors may be more important determinants of illicit trade (Joossens and Raw, 1998; Joossens et al., 2009).

Figure 2. Unrecorded alcohol consumption in a selection of countries at different income levels

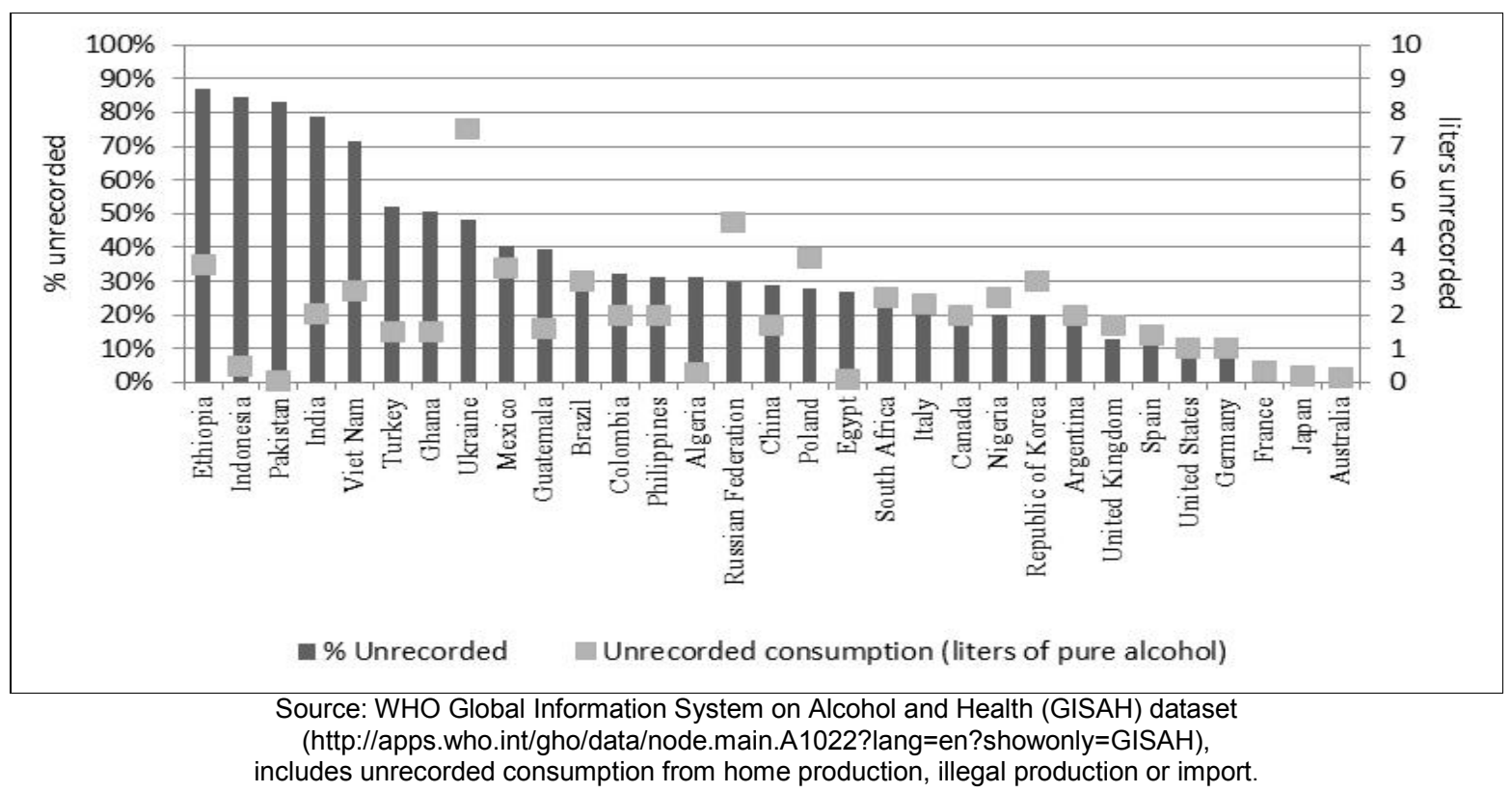




\section{SECTION IV - OTHER FISCAL MEASURES}

\section{Fiscal measures potentially available for health promotion}

62. While commodity taxes are, by far, the fiscal measures most widely used to influence the consumption of health-related commodities, a much broader range of options are available to governments wishing to use fiscal levers to support public health strategies. The diagram in Figure 3 provides a synoptic view of different types of fiscal measures potentially suitable for health promotion. While taxes tend to make health-related options less affordable, other fiscal measures, some examples of which are discussed in the remainder of this section, may rather aim at making healthier options more affordable.

Figure 3. Fiscal measures with a potential for use in health promotion

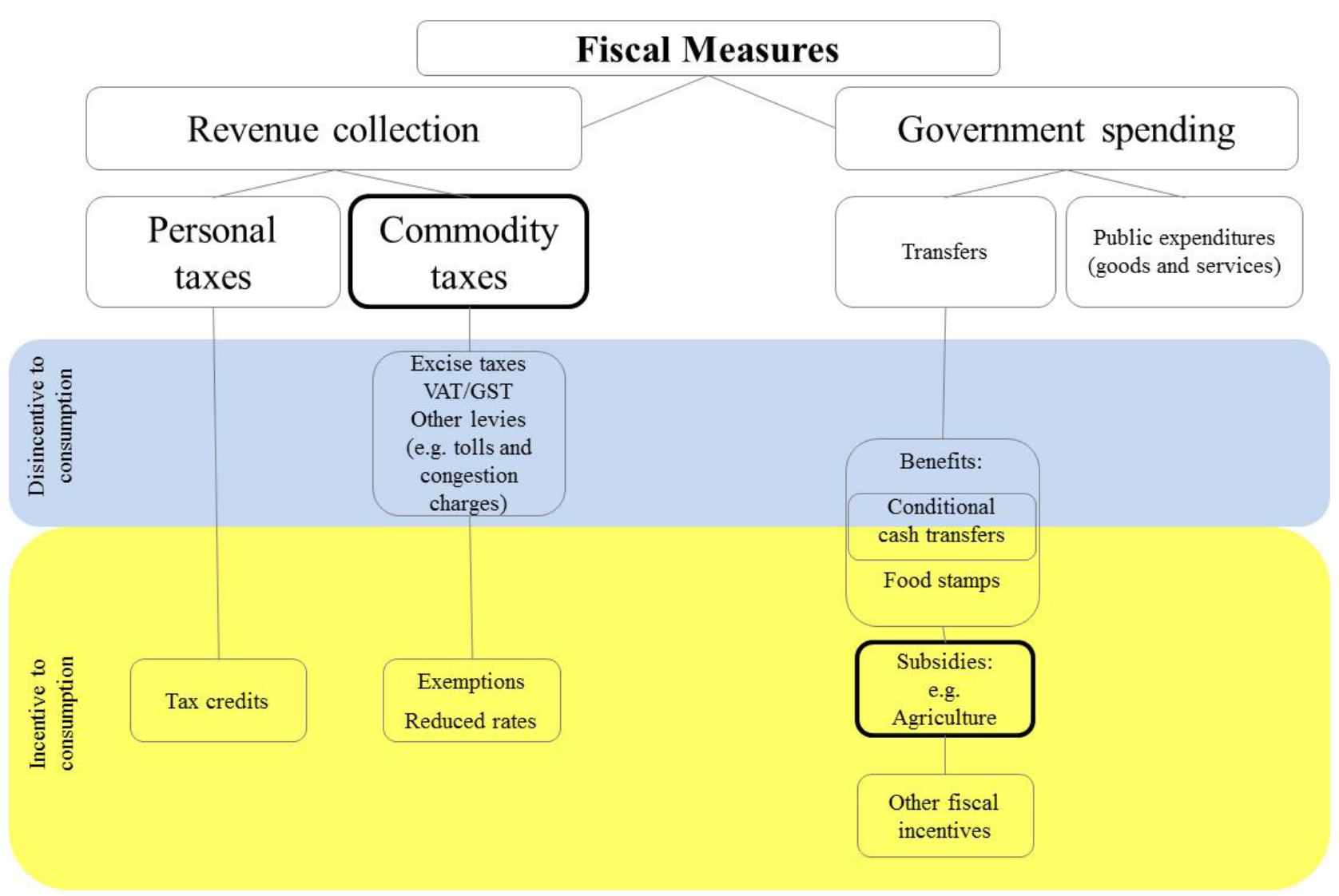

Policies directly affecting commodity prices 


\subsection{Commodity subsidies}

63. Commodity subsidies are in widespread use in areas of government policy that are relevant for public health, such as agriculture. However, existing agricultural subsidies have been typically designed to pursue objectives other than health promotion. Subsidies on fruit, vegetables and other healthy foods can change people's diets and improve their health (An, 2013). A review of US studies shows that lower fruit and vegetable prices tend to reduce body weight, particularly in adolescents and low-income people (Powell et al., 2013). However, much of the debate has been on farm-commodity, rather than final-product, subsidies. For instance, there have been suggestions that price reductions for certain farm commodities (e.g. soybean, corn) encouraged food manufacturers to use derived ingredients (e.g. high-fructose corn syrup and partially hydrogenated vegetable oils), which in turn decreased the prices of processed foods (Wallinga et al., 2009). On the other hand, it has been argued that the EU sugar policy in force up to 2006 (including a price floor, import duties, export subsidies and quotas) effectively raised the price of sugar, implicitly curbing its consumption (Bonnet and Requillart, 2011). Evidence of the effects on nutrition and health of agricultural policies (of which subsidies are an important component) is largely lacking, and the links are still poorly understood (Alston et al., 2006). It is widely held that, even when fully passed on to consumers, farm-commodity subsidies have a small impact on prices at the point of consumption (Alston et al., 2008).

64. In a detailed study comparing a range of tax and subsidy options, Okrent and Alston (2012) concluded that eliminating farm subsidies in the United States, including grain subsidies and indirect subsidies from trade barriers on diary, sugar, and fruit and vegetables products would have a limited impact on calorie intake and on obesity. They also estimated that a subsidy on fruit and vegetable (final) products would be effective in increasing their consumption, and at the same time would reduce the consumption of cereal and bakery products, meat and non-alcoholic drinks. Such a subsidy would have more desirable effects than one on fruit and vegetable farm commodities.

65. In 2005, the Australian Government established the Petrol Sniffing Prevention Program, aimed at reducing the incidence and impact of petrol sniffing. Among other measures, the program provides subsidies for the production and distribution of low aromatic fuel, so that it can be supplied to fuel retailers and consumers for a price equivalent to regular unleaded petrol. The initiative has involved a partnership between the private sector, including both large and small businesses, all levels of government, nongovernment organisations, and Indigenous communities. This partnership has dramatically curbed the scourge of petrol sniffing, by over ninety percent in some places ${ }^{6}$. An evaluation in 2008 showed a $70 \%$ decline in the prevalence of sniffing (D'Abbs and Shaw, 2008).

\subsection{Individual subsidies and welfare benefits}

66. Subsidies may also be delivered directly to consumers, normally in the form of welfare benefits, which allows the targeting of population groups that are most at risk of health-related consumption (e.g. low-income households with children). Income transfer programs for food and beverage are in place in a number of countries, an example being the food stamp programme in the United States, but they are generally aimed at addressing food insecurity and preventing undernutrition, rather than improving diet quality. In fact, several studies have shown that these programmes may end up worsening the quality of beneficiaries' diets and their health by incentivising the purchase of energy-dense, and generally less healthy, foods (e.g. Bhargava and Amialchuk, 2007), and women may be particularly exposed to these

6

Information available at:

http://www.health.gov.au/internet/stoppetrolsniffing/publishing.nsf/Content/home-1; and, http://www.bp.com/genericarticle.do? categoryId=9008681\&contentId=7016191, accessed December 2013. 
risks (DeBono et al., 2012). However, the evidence available on the effects of the US food stamps programme is mixed (Alston et al., 2009).

67. Restricting individual food subsidies to the purchase of healthier foods has been proposed as a possible way of addressing nutrition quality and health issues (e.g. Zagorsky and Smith, 2009). However, subsidising the purchase of healthier foods may lead to increases in their demand and market prices (and correspondingly decrease the prices of less healthy foods), with possible detrimental effects on the diets of those who do not receive the subsidies, who are likely to be the majority of consumers (Alston et al., 2009; Guthrie et al., 2007). A possible solution to this issue may be the combined use of subsidies on healthier foods and taxes on less healthy foods (e.g. SSBs) (Faulkner et al., 2011).

\subsection{Conditional cash transfers}

68. The receipt of welfare benefits can be made conditional upon certain actions or requirements, as in conditional cash transfers. There is some evidence that these types of welfare benefits contributed to reducing morbidity and to improving health, especially in children, in low-income settings (Huerta, 2006). Conditional cash transfers are also effective in increasing the use of preventive services and in improving nutritional outcomes (Lagarde et al., 2007). In Mexico, conditional cash transfer programs (Oportunidades) provide either a monthly fixed stipend to be spent on preventive medical care and healthy foods, or educational scholarships. An increase in the amount of the cash transfer to households was associated with improvements in child growth, development, and health, with a lower BMI and prevalence of overweight, an increased height for age and a higher haemoglobin concentration (Fernald et al., 2008). However, as in the case of individual subsidies discussed in the previous section, there is a risk that conditional cash transfers may lead to excess energy consumption by some beneficiaries (Leroy et al., 2010).

\subsection{Tax credits}

69. Further positive incentives for healthy consumption may derive from targeted personal tax credits. An example is the Children's Fitness Tax Credit (CFTC), introduced by the Canadian government in 2007, which provides a tax credit of up to $\$ 500$ for those who register children under 16 years of age in a physical activity program. An evaluation of the programme showed that awareness and uptake were significantly skewed in favour of wealthier income groups (Spence et al., 2010). Although the CFTC affects Canadian tax revenues, increased levels of physical activity are expected to lead to lower healthcare costs and reduced absence from work due to obesity-related diseases. A recent analysis concluded that, among fiscal measures potentially available to tackle obesity, fitness tax credits are likely to have the most lasting positive effects on health and revenue gains, and should best be coupled with communication strategies emphasising the importance of healthy lifestyles (Reach, 2012). 
DELSA/HEA/WD/HWP(2013)7

\section{SECTION V - CONCLUSIONS}

70. In recent years, an increased attention has been placed by many governments on the use of fiscal measures, particularly taxes on health-related commodities, as a means of promoting health and preventing chronic diseases. While taxes on tobacco products and alcoholic beverages have been widely used for a long time, fewer countries have used taxes on selected foods and non-alcoholic beverages with the aim of improving health by curbing excessive consumption. This paper is meant to support policy decisions on the adoption of new taxes, or changes in existing taxes, by providing a comprehensive review of the potential and the limitations, the benefits and the risks, of taxes on the commodities that are most directly linked with health and longevity, including tobacco and alcohol products, food and non-alcoholic beverages.

71. From a public health standpoint, taxes on health-related commodities may be beneficial when one or more of the following conditions are met: (a) they contribute to correcting important externalities; (b) they have the potential to shift consumption towards healthier patterns; (c) they can justify the use of incremental resources in the fight against the diseases linked with the consumption of the commodities in question; (d) they contribute to reducing health disparities; and, (e) the benefits associated with any or all of the above are not offset by the potentially negative impacts outlined in Section III.

72. Of those discussed in this paper, taxes on tobacco and alcohol products tend to fulfil the largest number, if not all, of the above criteria. Important externalities exist in the consumption of both sets of commodities, which can be redressed, at least in part, by taxation. Their demand is not particularly responsive to price changes, but existing tax rates are so high to result in meaningful shifts in consumption patterns. The inelastic demand makes tax revenues especially large, which provides a strong argument for increased expenditure to support the pursuit of public health goals. Less affluent consumers are likely to gain more from taxation, in terms of improved health, because they are more responsive to price changes and they are more likely to suffer the disease consequences of smoking and alcohol abuse. Of the potential negative consequences of taxation, welfare losses are unlikely to be of major concern in the case of tobacco and alcohol taxes, because of the gains associated with tackling the corresponding externalities. Regressive financial effects are possible, especially for smoking, but the greater responsiveness of lowincome smokers suggests that the effects of incremental changes in taxation may vary in different settings. Finally, smuggling and illicit trade are very important phenomena in tobacco and alcohol markets, but little is known on how changes in taxation may affect them.

73. A case for the taxation of selected foods and non-alcoholic beverages can also be made, but the arguments for it are less clear-cut. In particular, externalities are less evident than in the case of tobacco and alcohol, which means that possible welfare losses may be more of a concern for policy makers. Regressive effects may also be important if tax rates are to be set at a sufficiently high level to cause a meaningful change in consumer demand (we showed that elasticity for many foods is very low). There is also a suggestion that food prices may be increased by more than the amount of the tax in oligopolistic markets, which needs to be accounted for in balancing the positive and negative effects of a tax. On the other hand, regressive effects could be alleviated through income redistribution measures (e.g. targeted welfare benefits), especially considering that revenues from taxes on foods and non-alcoholic beverages are likely to be large. Illicit trade is also likely to be less of a concern than in the case of tobacco and alcohol. In the case of SSBs, which have been at the centre of the food taxation debate in recent years, consumers are more responsive to price changes than for most foods, which means that tax rates do not have to be very high to cause a meaningful shift in consumption, resulting in milder regressive effects. 
There appears to be scope for using taxes to encourage substitution across beverage types, although existing studies suggest that low-calorie drinks may not be viewed as a substitute for SSBs, as their demand may even be complementary to that for the latter.

74. The main argument commonly used by critics of taxes on health-related commodities, i.e. that taxes are not useful for public health purposes because of a limited response by consumers, is unfounded. An inelastic demand makes taxes more likely to be passed on to consumers, it means that consumers are less likely to substitute the taxed product with others, and it ensures substantial revenues. Welfare losses may be an issue in the case of food taxes, but they have to be balanced with the health gains those taxes may produce. Health gains from all taxes on health-related commodities tend to be progressive, and may balance, at least to some extent, regressive financial effects.

75. Political and electoral considerations may heavily influence governments' decisions about the taxation of health-related commodities. An important objective for governments is to finance public expenditures minimizing popular dissent on the means used for revenue collection. While taxes on goods understood as harmful by most (e.g. tobacco, alcohol, gambling) tend to be more accepted by the general public, other levies, such as congestion charges and environmental taxes, as well as most food taxes, tend to be unpopular, therefore they are used sparingly by governments, sometimes missing opportunities to improve societal welfare (Frey, 2005).

76. In conclusion, based on existing evidence, taxes on health-related commodities can be a powerful tool for health promotion, but the variety and complexity of the effects they generate require careful consideration by policy makers intending to adopt new taxes or reform existing ones. Taxes have some clear strengths in comparison with other public health measures, but also have potential negative effects on individual consumers, social welfare, and the economy as a whole, which can be addressed, at least in part, with a careful design. 


\section{REFERENCES}

Ahmad, S. (2005), "Increasing excise taxes on cigarettes in California: a dynamic simulation of health and economic impacts", Preventive Medicine, No. 41: pp. 276-283.

Allais, O., P. Bertail and V. Nichèle (2010), "The effects of a "Fat Tax" on French Households' purchases: a nutritional approach", Amer. J. Agr. Econ. 92 (1): 228-245Alemanno, A. and I. Carreño (2012),

"Fat taxes' in Europe - A Legal and Policy Analysis under EU and WTO Law", HEC Policy Paper.

Alm, J. and M. Melnik (2005), "Sales taxes and the decision to purchase online". Public Finance Review, No. 33 (2), pp. 184-212.

Alston, J.M., D.A. Sumner, S.A. Vosti (2006), "Are Agricultural Policies Making Us Fat? Likely Links Between Agricultural Policies and Human Nutrition and Obesity, and their Policy Implications. Review of Agricultural Economics", No. 28(3), pp. 313-322.

Alston, J.M., D.A. Sumner, S.A. Vosti (2008), "Farm subsidies and obesity in the United States: National evidence and international comparisons", Food policy, No. 33, pp. 470-479.

Alston, J.M. et al. (2009), "Likely effects on obesity from proposed changes to the US food stamp program. Food Policy", No. 34, pp. 176-184.

An, R. (2013), "Effectiveness of subsidies in promoting healthy food purchases and consumption: a review of field experiments", Public Health Nutrition, No. 16 (07), pp. 1215-1228.

Anderson, P. (2009), "Is it time to ban alcohol advertising?", Clinical Medicine, No. 9, pp. 121-124.

Anderson, S.P., A. de Palma and B. Kreider (2001), "Tax incidence in differentiated product oligopoly", Journal of Public Economics, No. 81, pp. 173-192.

Anderson, P. and B Baumberg (2006), "Alcohol in Europe. A public health perspective. A report for the European Commission".

Andreyeva, T., M.W. Long and K.D. Brownell (2010), "The Impact of Food Prices on Consumption: A Systematic Review of Research on the Price Elasticity of Demand for Food", Am J Public Health No. 100, pp. 216-222.

Andreyeva, T., F.J. Chaloupka and Brownell (2011), "Estimating the potential of taxes on sugar-sweetened beverages to reduce consumption and generate revenue", Preventive Medicine No. 52, pp. 413-416.

Atkinson, A. and J.E. Stiglitz (1976), "The Design of Tax Structure: Direct Versus Indirect Taxation", Journal of Public Economics, No. 6, pp. 55-75.

Atkinson, A.B. (1997), "Optimal taxation and the direct versus indirect tax controversy", The Canadian Journal of Economics, Nov., Vol. 10, No. 4. pp. 590-606.

Ayyagari, P., et al. (2013). "Understanding heterogeneity in price elasticities in the demand for alcohol for older individuals", Health Economics, No. 22(1), pp. 89-105. 
Babor, T.F., R. Caetano, S. Casswell, et al. (2010), "Alcohol: no ordinary commodity. Research and public policy", Oxford: Oxford University Press; $2^{\text {nd }}$ Edition.

Beatty, T.K.M., Larsen, E.R., Sommervoll, D.E. (2009), "Driven to drink: Sin taxes near a border", Journal of Health Economics, No. 28, pp. 1175-1184.

Berardi N. et al. (2012), "The impact of a 'Soda tax'on prices. Evidence from French micro data”, Banque de France, Working paper 415

Bergman, U.M. and N.L. Hansen (2013), "Are excise taxes on beverages fully passed through to prices? The Danish experience", Unpublished working paper, University of Copenhagen, retrieved at http://www.econ.ku.dk/okombe.

Barnett P.G., Keeler T.E., Hu, T. (1995), Oligopoly structure and the incidence of cigarette excise taxes, Journal of Public Economics, Vol. 57, No. 3, pp. 457-470Bhargava, A., A.Amialchuk (2007),

"Added sugars displaced the use of vital nutrients in the National Food Stamp Program Survey". $J$ Nutr, No. 137(2), pp. 453-460.

Bonnet, C. and V. Requillart (2011), "Does the EU sugar policy reform increase added sugar consumption? An empirical evidence on the soft drink market", Health Econ, No. 20(9), pp. 1012-1024.

Bonnet, C. and V. Requillart (2012), "Sugar Policy Reform, Tax Policy and Price Transmission in the Soft Drink Industry", Working Paper No. 4, Transparency of Food Pricing, TRANSFOP.

Bonnet, C. and V. Requillart (2013), "Impact of cost shocks on consumer prices in vertically-related markets: the case of the French soft drink market", Am. J. Agr. Econ. 95 (5): 1088-1108.

Briggs AD, et al. (2013), Overall and income specific effect on prevalence of overweight and obesity of $20 \%$ sugar sweetened drink tax in UK: econometric and comparative risk assessment modelling study. BMJ. 2013 Oct 31;347:f6189.

Byrnes, J., et al. (2012), "The efficiency of a volumetric alcohol tax in Australia", Appl Health Econ Health Policy, No. 10(1), pp. 37-49.

Cameron, L., and Williams J. (2001), "Cannabis, Alcohol and Cigarettes: Substitutes or Complements?", The Economic Record, Vol. 77, No. 236, pp. 19-34.

Chaloupka, F.J., et al. (2000), "The taxation of tobacco products. In Tobacco control in developing countries", edited by Jha P, Chaloupka F., Oxford University Press, New York, pp. 237-272.

Chaloupka, F.J., et al. (2002), "Tax, price and cigarette smoking: evidence from the tobacco documents and implications for tobacco company marketing strategies", Tobacco Control, No. 11(Suppl I):pp. i62-i72.

Chaloupka, F.J., A. Yurekli and Fong (2012), "Tobacco taxes as a tobacco control strategy", Tobacco Control, No. 21, pp. 172-180.

Chiou, L. and E. Muehlegger (2010), "Consumer Response to Cigarette Excise Tax Changes", HKS Faculty Research Working Paper Series, RWP10-020, John F. Kennedy School of Government, Harvard University. 
Chouinard, H.H., et al. (2007), "Fat Taxes: Big Money for Small Change. Forum for Health Economics \& Policy". Vol. 10, Issue 2, Article 2.

Cnossen, S. (2005), "Theory and Practice of Excise Taxation: Smoking, Drinking, Gambling, Polluting, and Driving", Oxford: Oxford University Press.

Cobiac, L., et al. (2009), "Cost-effectiveness of interventions to prevent alcohol-related disease and injury in Australia. Addiction", No. 104(10), pp. 1646-1655.

Collis, J., A. Grayson and S. Johal (2010), "Econometric analysis of alcohol consumption in the UK", HM Revenue \& Customs Working Paper 10.

Czubek, M., and S. Johal (2010), "Econometric analysis of cigarette consumption in the UK", HMRC Working Paper, No. 9.

D'Abbs P. and G. Shaw (2008), Executive summary of the "Evaluation of the impact of Opal fuel". Canberra: Department of Health and Ageing, Australia, available at: http://www.health.gov.au/internet/stoppetrolsniffing/publishing.nsf/Content/708AC851B8897457C A2579A40006F5C0/\$File/opalimp.pdf

DeBono, N.L., N.A. Ross, L. Berrang-Ford (2012), "Does the Food Stamp Program cause obesity? A realist review and a call for place-based research", Health \& Place, No. 18, pp. 747-756.

DeCicca, P., D. Kenkel and F. Liu (2010), "Who Pays Cigarette Taxes? The Impact of Consumer Price Search", NBER Working Paper, March.

Decker, S.L. and A.E. Schwartz (2000), "Cigarettes and Alcohol: Substitutes or Complements?" NBER Working Paper No. 7535, issued in February.

Dharmasena S. and O. Capps (2012), "Intended and unintended consequences of a proposed national tax on sugar-sweetened beverages to combat the U.S. obesity problem", Health Econ., No. 21, pp. 669-694.

Diamond, P.A. (1975), "A many-person Ramsey tax rule", Journal of Public Economics, No. 4, pp. 335-342.

Elder, R.W., B. Lawrence, A. Ferguson, et al. (2010), Task Force on Community Preventive Services, The effectiveness of tax policy interventions for reducing excessive alcohol consumption and related harms, American Journal of Preventive Medicine, No. 38(2), pp. 217-229.

Eriksen, M., J. Mackay and H. Ross (2012), "The Tobacco Atlas", Fourth Ed. Atlanta, GA: American Cancer Society; New York, NY: World Lung Foundation, also available at www.TobaccoAtlas.org.

Evans, C. (2003), "Studying the studies: an overview of recent research into taxation operating costs", eJournal of Tax Research, No. 1(1), pp. 64-92.

Eyles, H., et al. (2012), "Food Pricing Strategies, Population Diets, and Non-Communicable Disease: A Systematic Review of Simulation Studies", PLoS Med, No. 9(12), e1001353, oi:10.1371/journal.pmed.1001353.

European Commission (2012), "VAT rates applied in the Member States of the European Union". 
European Commission (2004), "Tobacco or health in the European Union. Past, Present and Future", EU http://ec.europa.eu/taxation_customs/taxation/excise_duties/gen_overview/index_en.htm

Faulkner, G.E.J., et al. (2011), "Economic instruments for obesity prevention: results of a scoping review and modified Delphi survey", International Journal of Behavioral Nutrition and Physical Activity, No. 8, pp. 109.

Fernald, L.C.H, P.J. Gertler, L.M. Neufeld (2008), "The importance of cash in conditional cash transfer programs for child health, growth and development: an analysis of Mexico's Oportunidades", Lancet, No. 371(9615), pp 828 - 837.

Finkelstein, E.A. et al. (2013), "Implications of a sugar-sweetened beverage (SSB) tax when substitutions to non-beverage items are considered", Journal of Health Economics, No. 32, pp. 219 - 239.

Fisher, R.C. (2007), "State and local public finance", 3rd ed. Mason: Thompson South-Western.

Fletcher, J.M., D.E. Frisvold and N. Tefft (2010), "The effects of soft drink taxes on child and adolescent consumption and weight outcomes", Journal of Public Economics No. 94, pp. 967-974.

Fogarty, J. (2006), "The nature of the demand for alcohol: Understanding elasticity", British Food Journal, No. 108(4), pp. 316-332.

Fogarty, J. (2008), "The Demand for Beer, Wine and Spirits: Insights from aMeta. Analysis Approach", AAWE Working Paper, No. 31.

Frey, B.S. (2005), "Excise Taxes: Economics, Politics and Psychology, in Sijbren Cnossen, Theory and Practice of Excise Taxation: Smoking, Drinking, Gambling, Polluting, and Driving", Oxford: Oxford University Press.

Gallet, C.A. and J.A. List (2003), "Cigarette demand: a meta-analysis of elasticities", Health Econ. 12, pp. 821-835.

Gallet, C.A. (2007), "The Demand for Alcohol: A Meta-analysis of Elasticities", Australian Journal of Agricultural and Resource Economics, No. 51(2), pp. 121-135.

Gallet C. A. (2010), "Meat meets meta: a quantitative review of the price elasticity of meat. Am J Agric Econ; $92: 258-72$

Goel, R. K. and M.A. Nelson (2005), "Tobacco policy and tobacco use: differences across tobacco types, gender and age", Applied Economics, No. 37, pp. 765-771.

Goel, R. K. and M.A. Nelson (2006), "The Effectiveness of anti-smoking legislation: a review. Journal of Economic Surveys, Vol. 20, No. 3.

Goldman, D., D. Lakdawalla and Y. Zheng (2009), "Food Prices and the Dynamics of Body Weight", Washington, DC, NBER Working Paper No. 15096.

Goolsbee, A. M., M.F. Lovenheim and J. Slemrod (2007), "Playing with fire: Cigarettes, taxes and competition from the internet. Policy Paper", 07-002, Stanford Institute for Economic Policy Research. 
Gospodinov, N. and I. Irvine (2009), "Tobacco taxes and regressivity", Journal of Health Economics, No. 28, pp. 375-384.

Green R, et al, (2013) "The effect of rising food prices on food consumption: systematic review with metaregression.” BMJ, Jun 17;346:f3703.

Griffith, R., L. Nesheim and M. O'Connell (2010), "Sin taxes in differentiated product oligopoly: an application to the butter and margarine market", Working paper, November 30.

Gruber J., A. Sen and M. Stabile (2003), "Estimating price elasticities when there is smuggling: the sensitivity of smoking to price in Canada", Journal of Health Economics, No. 22, pp. 821-842.

Gurthrie, J.F. et al. (2007), "Can Food Stamps Do More to Improve Food Choices? An Economic Perspective". USDA, Economic Information Bulletin, No. 29-1.

Harding, M., E. Leibtag and M.F. Lovenheim (2012), "The Heterogeneous Geographic and socioeconomic Incidence of Cigarette Taxes: Evidence from Nielsen Homescan Data", American Economic Journal: Economic Policy, No. 4(4), pp. 169-198.

Heady, C. (2013). "The effect of ageing on the financing of social health provision", paper presented at the 2nd Meeting of the OECD Joint Network on Fiscal Sustainability of Health Systems, Paris, 25-26 March 2013.

HM Revenue \& Customs (2012), "Measuring tax gaps 2012 - Tax gap estimates for 2010-11", an official statistics release, 18 October 2012, available at: http://www.hmrc.gov.uk/statistics/tax-gaps/mtg2012.pdf.

HM Revenue \& Customs (2013), "Statistical note: revision and updating of the administrative burdens baseline", 1 January 2013, available at: http://www.hmrc.gov.uk/transparency/stats-note-adminburden.pdf

Holm AL, et al. (2013) The health benefits of selective taxation as an economic instrument in relation to IHD and nutrition-related cancers. Public Health Nutr. 2013 Dec;16(12):2124-31.

Holt, E. (2011), "Hungary to introduce broad range of fat taxes", The Lancet, Vol 378 August 27.Hu, T., X. Xu and T. Keeler (1998), "Earmarked tobacco taxes: Lessons learned", in Abedian I, van der Merwe R, Wilkins N, Jha P. (eds). The Economics of Tobacco Control. Towards an optimal policy mix. Cape Town: Applied Fiscal Research Centre, University of Cape Town, pp. 102-118.

Huang, J. and F. Chaloupka (2011), "The economic impact of state cigarette taxes and smoke-free air policies on convenience stores", Research Paper Series, No. 40.

Hurley, S. (2005), "Short-term impact of smoking cessation on myocardial infarction and stroke hospitalisations and costs in Australia", MJA, No. 183 (1), pp. 13-17.

Jensen J.D. and S. Smed (2013), “ The Danish tax on saturated fat - Short run effects on consumption, substitution patterns and consumer prices of fats”, Food Policy, 2013, vol. 42, issue C, pp 18-31

Jha, P., and F. J. Chaloupka. (1999). "Curbing the Epidemic: Governments and the Economics of Tobacco Control", Washington, DC, World Bank. 
Jha, P. and F.J. Chaloupka (2000), "The economics of global tobacco control", BMJ, No. 321, pp. 358-361.

Joossens, L. and M. Raw (1998), "Cigarette smuggling in Europe: who really benefits?", Tobacco Control, No. 7, pp. 66-71.

Joossens, L., et al. (2009), "How eliminating the global illicit cigarette trade would increase tax revenue and save lives", Paris: International Union Against Tuberculosis and Lung Disease.

Keeler, T.E., et al. (1996), "Do cigarette producers price-discriminate by state? An empirical analysis of local cigarette pricing and taxation". Journal of Health Economics, No. 15, pp. 499-512.

Keng S. and W. Huffman (2010), "Binge drinking and labor market success: a longitudinal study on young people," J Popul Econ, vol. 23(1), pp 303-322

Kenkel, D.S. (2005), "Are alcohol tax hikes fully passed through to prices? Evidence from Alaska", American Economic Review, No. 95, pp. 273-277.

Kim D. and I. Kawachi (2006), "Food taxation and pricing strategies to 'thin out' the obesity epidemic". Am J Prev Med., May; No. 30(5), pp. 430-437.

Koksal A. and M. Wohlgenant (2011), "Alcoholic Beverages and Cigarettes: Complements or Substitutes? A Pseudo Panel Approach". Southern Agricultural Economics Association 2011 Annual Meeting, February 5-8, Corpus Christi, Texas.

Koski A., et al. (2007), "Alcohol tax cuts and increase in alcohol-positive sudden deaths: a time-series intervention analysis", Addiction, No. 102(3), pp. 362-368.

Kotakorpi, K. (2008), "The incidence of sin taxes. Economics letter", No. 98, pp. 95-99.

KPMG LLP (2006), “Administrative Burdens - HMRC Measurement Project”, 20 March 2006

Kuo, M, J.L. Heeb, G. Gmel, and J. Rehm (2003), "Does price matter? The effect of decreased price on spirits consumption in Switzerland. Alcoholism Clinical and Experimental Research", No. 27(4), pp. 720-725.

Leicester, A. and F. Windmeijer (2004), "The 'fat tax': economic incentives to reduce obesity", Institute for Fiscal Studies, Briefing Note No. 49.

Leppänen, K., R. Sullström and I. Suoniemi (2001), "The Consumption of Alcohol in Fourteen European Countries. A comparative Econometric Analysis", Helsinki: Stakes.

Leroy JL, et al., "Cash and in-kind transfers in poor rural communities in Mexico increase household fruit, vegetable, and micronutrient consumption but also lead to excess energy consumption", J Nutr. 2010 Mar;140(3):612-7.

Levy, D.T., F.J. Chaloupka and J. Gitchell (2004), "The effects of tobacco control policies on smoking rates: a tobacco control scorecard", J Public Health Manag Pract, No. 10(4), pp. 338-353.

Lhachimi SK, et al. (2012), "Health impacts of increasing alcohol prices in the European Union: A dynamic projection", Preventive Medicine, No. 55(3), pp. 237-243. 
Lin, B.H., et al. (2011), "Measuring weight outcomes for obesity intervention strategies: The case of a sugar-sweetened beverage tax", Economics and Human Biology, No. 9, pp. 329-341.

Liu, E., W-C. Yu and H-L Hsieh (2011), "Cigarette Taxes and Respiratory Cancers: New Evidence from Panel Co-Integration Analysis", J Health Care Finance, No. 37(3), pp. 62-71.

Lockwood, B. and G. Migali (2009), "Did the Single Market Cause Competition in Excise Taxes? Evidence from EU Countries", The Economic Journal, Vol. 119, Issue 536, pp. 406-429, March.

Mäkelä P, et al. (2008), "Changes in volume of drinking after changes in alcohol taxes and travellers' allowances: results from a panel study", Addiction, Feb; No. 103(2), pp. 181-191.

Mäkelä, P. and E. Österberg (2009), "Weakening of one more alcohol control pillar: a review of the effects of the alcohol tax cuts in Finland in 2004", Addiction, No. 104(4), pp. 554-563.

Mankiw, N.G., M. Weinzierl and D. Yagan (2009), "Optimal taxation in Theory and Practice". NBER Working Paper Series. June.

Meier, P. (2008), "Independent review of the effects of alcohol pricing and promotion - part B: modeling the potential impact of pricing and promotion policies for alcohol in England: results from the Sheffield alcohol policy model", Sheffield: University of Sheffield.

Meier, P.S., R. Purshouse and A. Brennan (2010) "Policy options for alcohol price regulation: the importance of modeling population heterogeneity", Addiction, No. 105(3), pp. 383-393.

Miao, Z., J.C. Beghin and H.H. Jensen (2012), "Taxing sweets: sweetener input tax or final consumption tax?" Contemporary Economic Policy, Vol. 30, No. 3, pp. 344-361.

Miao, Z., J.C. Beghin and H.H. Jensen (2013), "Accounting for product substitution in the analysis of food taxes targeting obesity" Health Econ. 22: 1318-1343

Michael, J. (2012), Research Department Minnesota House of Representatives, Policy Brief.

Mytton, O., et al. (2007), "Could targeted food taxes improve health?", J Epidemiol Community Health No. 61, pp. 689-694.

Moylan J. (2012), "Will weaker beers help the brewing industry?" London: BBC website; 2012, available at: http://www.bbc.co.uk/news/business-17399368.

Mozaffarian D, M.F. Jacobson and J.S. Greenstein (2010), "Food reformulations to reduce trans fatty acids", New England Journal of Medicine, No. 362(21), pp. 2037-2039.

Nelson JP (2013)a "Meta-analysis of alcohol price and income elasticities - with corrections for publication bias", Health Econ Rev. 2013 Jul 24;3(1):17.

Nelson JP (2013)b "Gender differences in alcohol demand: a systematic review of the role of prices and taxes" Health Econ. Published online in Wiley Online Library (wileyonlinelibrary.com)

Nnoaham, K.E., et al. (2009), "Modelling income group differences in the health and economic impacts of targeted food taxes and subsidies", International Journal of Epidemiology, No. 38, pp. 1324-1333. 
OECD (2012), "Consumption Tax Trends 2012: VAT/GST and Excise Rates, Trends and Administration Issues", OECD Publishing. http://dx.doi.org/10.1787/ctt-2012-en.

Ohsfeldt, R. L. and R.G. Boyle (1994), "Tobacco excise taxes and rates of smokeless tobacco use in the U.S.: an exploratory ecological analysis", Tobacco Control No. 3, pp. 316-323.

Okrent, A.M. and J.M. Alston (2012), "The effects of farm commodity and retail food policies on obesity and economic welfare in the United States", Amer. J. Agr. Econ. No. 94(3), pp. 611 - 646.

ONS, Office of National Statistics (2011), "The effects of alcohol and tobacco duties on household disposable income", available at: http://www.ons.gov.uk/ons/rel/household-income/the-effect-ofalcohol-and-tobacco-duties-on-household-disposable-income/2011/index.html.

Pacula, R. (1998), "Does increasing the beer tax reduce marijuana consumption?", Journal of Health Economics, No. 17, pp. 557-585.

Patterson, T.E. and S.E. Brittain (2003), "Alcohol Pricing and Excise Tax: A Case Study of the Implementation of a Best Practices as Part of the Enforcement of Underage Drinking Laws", Winston-Salem NC, Wake Forest University School of Medicine.

Peck R, et al. (2000), "A welfare analysis of tobacco use", in P Jha and F Chaloupka, eds., Tobacco Control in Developing Countries, Oxford University Press: Oxford, 2000

Petry, N.M. (2001), "A behavioral economic analysis of polysubstance abuse in alcoholics: asymmetrical substitution of alcohol and cocaine", Drug Alcohol Depend. No. 62, pp. 31-39.

Pierani, P. and S. Tiezzi (2005), "Addiction and the Interaction between Alcohol and Tobacco Consumption",Department of Economics University of Siena, Department of Economics, University of Siena.

Powell, L.M., J. Chriqui and F.J. Chaloupka (2009), "Associations between State-level Soda Taxes and Adolescent Body Mass Index", Journal of Adolescent Health, No. 45, pp. S57-S63.

Powell, L.M. and F.J. Chaloupka (2009), "Food prices and obesity: evidence and policy implications for taxes and subsidies", Milbank Q.; No. 87(1), pp. 229-257.

Powell, L.M., et al. (2013), "Assessing the potential effectiveness of food and beverage taxes and subsidies for improving public health: a systematic review of prices, demand and body weight outcomes", Obesity Reviews, No. 14, pp. 110-128.

Purshouse RC, et al. (2010), "Estimated effect of alcohol pricing policies on health and health economic outcomes in England: an epidemiological model", Lancet; No. 375(9723), pp. 1355-1364.

Rabinovich, L., et al. (2012), "Further Study on the affordability of alcoholic beverages in the EU", Cambridge, RAND Europe.

Ramsey, F.P. (1927), "A contribution to the theory of taxation", Economic Journal No. 37, 47-61.

Reach, D.M. (2012). "Fitness tax credits: Costs, Benefits, and Viability", Northwestern Journal of Law \& Social Policy, Vol. 7. 
Sandford, C., M. Godwin and P. Hardwick (1989), "Administrative and compliance costs of taxation", Fiscal Publications, Bath.

Sassi, F. (2010), Obesity and the economics of prevention: fit not fat. Paris, OECD Publishing.

Sassi, F., Cecchini, M., Lauer, J., Chisholm, D. (2009), "Improving lifestyles, tackling obesity: the health and economic impact of prevention strategies", OECD Health Working Papers, No. 48, OECD Publishing. http://dx.doi.org/10.1787/220087432153.

Schmitt, N.M., et al. (2007), "Health risks in tobacco farm workers - a review of the literature", $J$ Public Health, No. 15, pp. 255-264.

Smith, T.A., Lin, B-H., Lee J-Y. (2010), "Taxing caloric sweetened beverages: potential effects on beverage consumption, calorie intake and obesity", ERR-100, U.S. Department of Agriculture, Economic Research Service.

Spence, J.C. et al. (2010). "Uptake and effectiveness of the Children's fitness tax credit in Canada: the rich get richer", BMC Public Health, No. 10, pp. 356.

Sumnall, H., et al. (2004), "A behavioral economic analysis of alcohol, amphetamine, cocaine, and ecstasy purchases by polysubstance misusers", Drug and Alcohol Dependence, No. 76, pp. 93-99.

Sung, H.-Y., Hu.,T.-W. and Keeler, T.E. (1994), "Cigarette taxation and demand: An empirical analysis/model. Contemporary Economic Policy", No. 12(3), pp. 91-100.

Tariq, L., et al. (2009), "Cost-effectiveness of an opportunistic screening programme and brief intervention for excessive alcohol use in primary care", PLoS One, No. 20, pp. 343-356.

Thow, A.M., et al. (2010), "The effect of fiscal policy on diet, obesity and chronic disease: a systematic review", Bull World Health Organ, No. 88(8), pp. 609-614.

Tosun, M.S. and M.L. Skidmore (2007), "Cross-Border Shopping and the Sales Tax: An Examination of Food Purchases in West Virginia", The B.E. Journal of Economic Analysis \& Policy No. 7, Article 63.

Van den Berg, M., et al. (2008), "The cost-effectiveness of increasing alcohol taxes: a modelling study", BMC Med., No. 6. pp. 36.

Young, D.J and A. Bielinska-Kwapisz (2006), "Alcohol price, consumption, and traffic fatalities", Southern Economic Journal, No. 72(3), pp. 690-703.

Wagenaar AC, Tobler AL, Komro KA. (2010), "Effects of alcohol tax and price policies on morbidity and mortality: a systematic review", Am J Public Health, Nov, No. 100 (11), pp. 2270-2278.

Wagenaar A.C., M.J. Salois and K.A. Komro (2009), "Effects of beverage alcohol price and tax levels on drinking: a meta-analysis of 1003 estimates from 112 studies", Addiction, No. 104(2), pp. 179-190.

Wallinga, D., H. Schoonover, M. Muller (2009), "Considering the contribution of US Agricultural policy to the obesity epidemic: overview and opportunities", Journal of Hunger et Environmental Nutrition, No. $4: 1$, pp. $3-19$. 
Wang, H. (2011), "Paper: Optimal Indirect Taxation under Imperfect Competition", Peking University China Center for Economic Research (CCER).

WHO (2004), "Taxation of tobacco products in the WHO European Region: practices and challenges".

WHO (2007), "The European tobacco control report".

WHO (2010), "Technical manual on tobacco tax administration".

WHO (2012). "Tobacco taxation and innovative health-care financing".

Zagorsky, J.L. and P.K. Smith (2009), "Does the U.S. Food Stamp Program contribute to adult weight gain?", Economics and Human Biology, No. 7, pp. 246-258.

Zhang, N. (2010), Alcohol taxes and birth outcomes. Int.J.Environ.Res. Public Health 7: 1901-12.

Zhen, C., et al. (2011), "Habit formation and demand for sugar-sweetened beverages", American Journal of Agricultural Economics, No. 93(1), pp. 175-193.

Zhen, C., et al. (2013), "Predicting the effects of sugar-sweetend beverage taxes on food and beverage demand in a large demand system", Amer. J. Agr. Econ., pp. $1-25$. 
ANNEX

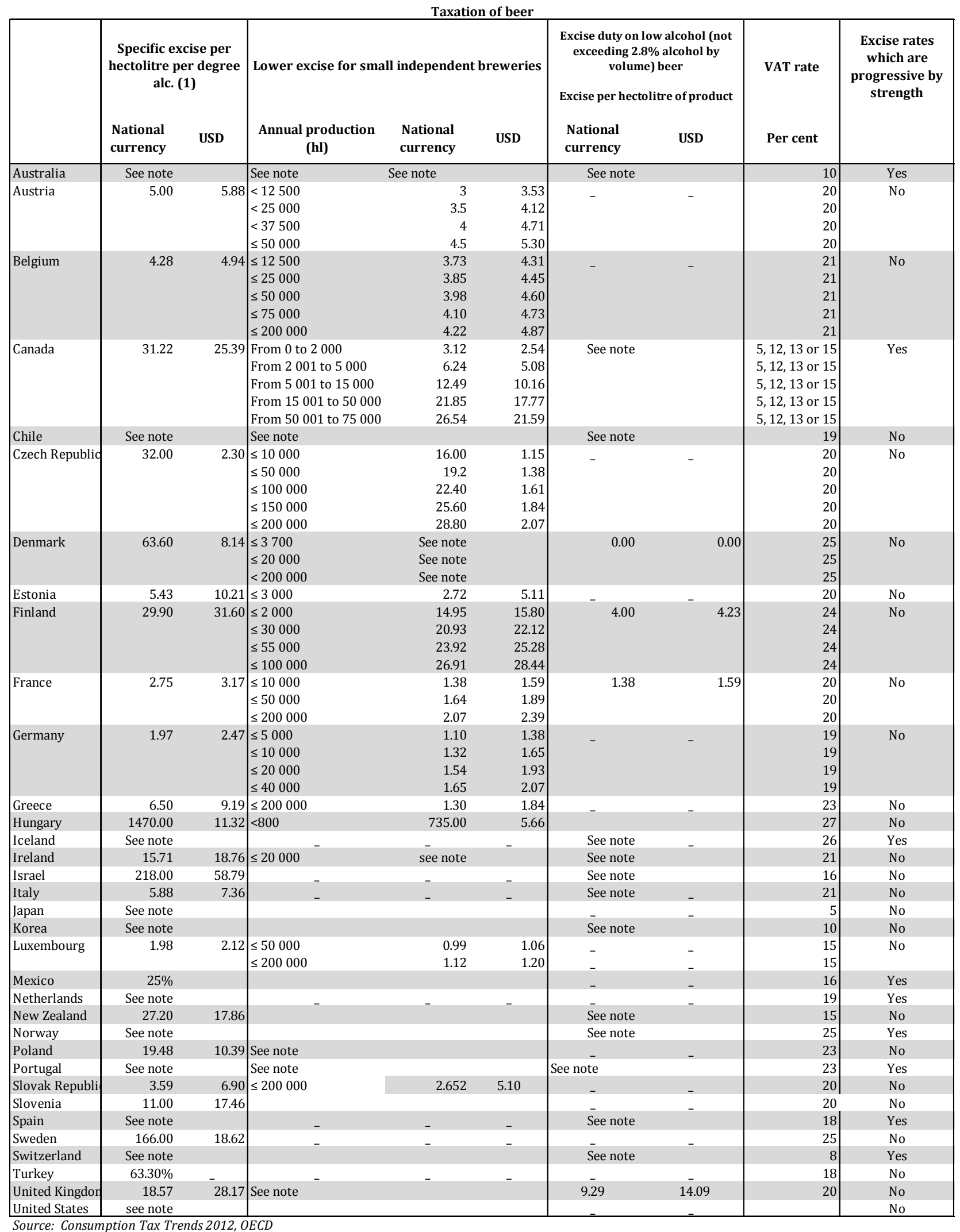


DELSA/HEA/WD/HWP(2013)7

\section{Country notes}

(1) In some countries the excise rate on beer is calculated per hectolitre per degree Plato. For ease of reading, all amounts have been converted in excise per hectolitre per degree of absolute alcohol. There is no precise conversion between degrees Plato and degrees of absolute alcohol but for tax purposes it is often assumed that $1 \%$ alcohol is equivalent to 2.5 degrees Plato. As a result, tax rates expressed in degree Plato have been multiplied by 2.5 to obtain the rates in degree alcohol.

Australia. Updated information provided by the Australian Government, different from the original source of the table. The excise rates for beer in individual containers not exceeding 48 litres are: AUD 38.70 per litre of alcohol where volume of alcohol does not exceed 3\%, AUD 45.08 where volume of alcohol exceeds 3\% but does not exceed 3.5\% and AUD 45.08 where volume exceeds $3.5 \%$. The rates for beer in individual containers exceeding 48 litres are: AUD 7.73 per litre of alcohol where volume of alcohol does not exceed 3\%, AUD 24.25 where volume of alcohol exceeds 3\% but not more than 3.5\%, and AUD 31.74 where volume exceeds 3.5\%. These rates apply as of 1 August 2011.

Each rate is calculated on the amount by which the alcohol content exceeds $1.15 \%$. Beer that does not contain more that $1.15 \%$ by volume of alcohol is free of excise. These rates are indexed to inflation in February and August each year. Breweries receive an excise refund of $60 \%$ of the excise paid up to a maximum of AUD 30000 per financial year provided the production of beer does not exceed 30000 litres.

Canada. The excise duty rates for beer (2.5\% absolute ethyl alcohol by volume or less) are: On the first 2000 hectolitres of beer and malt liquor brewed in Canada, if it contains more than $1.2 \%$ absolute ethyl alcohol by volume but not more than $2.5 \%$ absolute ethyl alcohol by volume, $\$ 1.561$ per hectolitre; if it contains not more than $1.2 \%$ absolute ethyl alcohol by volume, $\$ 0.2591$ per hectolitre. On the next 3000 hectolitres of beer and malt liquor brewed in Canada, if it contains more than $1.2 \%$ absolute ethyl alcohol by volume but not more than $2.5 \%$ absolute ethyl alcohol by volume, $\$ 3.122$ per hectolitre; if it contains not more than $1.2 \%$ absolute ethyl alcohol by volume, $\$ 0.5182$ per hectolitre. On the next 10000 hectolitres of beer and malt liquor brewed in Canada, if it contains more than $1.2 \%$ absolute ethyl alcohol by volume but not more than $2.5 \%$ absolute ethyl alcohol by volume, $\$ 6.244$ per hectolitre; if it contains not more than $1.2 \%$ absolute ethyl alcohol by volume, $\$ 1.0364$ per hectolitre. On the next 3000 hectolitres of beer and malt liquor brewed in Canada, if it contains more than $1.2 \%$ absolute ethyl alcohol by volume but not more than $2.5 \%$ absolute ethyl alcohol by volume, $\$ 10.927$ per hectolitre; if it contains not more

than $1.2 \%$ absolute ethyl alcohol by volume, $\$ 1.8137$ per hectolitre. On the next 25000 hectolitres of beer and malt liquor brewed in Canada, if it contains more than $1.2 \%$ absolute ethyl alcohol by volume but not more than $2.5 \%$ absolute ethyl alcohol by volume, $\$ 13.269$ per hectolitre; if it contains not more than $1.2 \%$ absolute ethyl alcohol by volume, $\$ 2.2024$ per hectolitre.

Chile. The sale of alcoholic beverages (including wine, beer, distilled alcoholic beverages and other alcoholic beverages) is subject to $19 \%$ VAT and also to surtax on the sale or import of alcoholic beverages. The rate applied to beer is of $15 \%$ and does not depend upon the degree of alcohol that the beer contains. The tax is applied to the VAT base, that is the sale's price (excluding VAT itself) and levies sales made between wholesale dealers. For sales between wholesalers, the tax paid to the vendor is creditable against the tax applied on sales at each stage of the value chain (including imports) until the last sale to the final retailer. The sale from the retailer to the final consumer is not subject to the surtax and the retailer cannot deduct the input tax.

Denmark. Lower rates on small independent breweries: production $\leq 3700 \mathrm{hl}$ receives a tax reduction of DKK 70 per hl; production $\leq 20000(\mathrm{X})$ receives a tax reduction of DKK $236.073 / \mathrm{X}+6.20$ per hl; production $<200000 \mathrm{hl}$ receives a tax reduction of DKK $20-\mathrm{X} / 10000$ per hl. An additional duty is placed on products which contains a mixture of beer and nonalcoholic drinks, Rates: DKK 8.15 pr. 1 of mixture with alcohol content $<=10 \%$ in the final product and DKK 14.80 pr. 1 of mixture with alcohol content $>10 \%$ in the final product.

Finland. Updated information provided by the Finnish Government, different from the original source of the table. Beer with an alcoholic content less than $0.5 \%$ vol. is free of excise.

Iceland. The duty in Iceland is ISK 91.33 per centilitre of alcohol per litre minus 2.25 centilitres. For example, one litre of beer that has $6 \%$ alc./vol. has 6 centilitres alcohol per litre. So the duty for one litre of beer that contains $6 \%$ alc./vol. would be as follows: (6-2.25) *91.33 = ISK 342.49 ISK. per litre. As a result of this formula, beer with less than $2.25 \%$ alc. vol. is not taxed.

Ireland. There is repayment of $50 \%$ alcohol products tax (excise duty) on beer brewed in independent small breweries producing up to $20000 \mathrm{hl}$ a year. For low alcohol beer, the rate is 0.00 (beer $\leq 1.2$ alc.) and EUR 7.85 (beer $>1.2$ up to 2.8 alc.).

Israel. The statistical data for Israel are supplied by and under the responsibility of the relevant Israeli authorities. The use of such data by the OECD is without prejudice to the status of the Golan Heights, East Jerusalem and Israeli settlements in the West Bank under the terms of international law. The duty was set as ILS 218 on 1 January 2012. The amount is updated each year according to the change in the Consumer Price Index (CPI). There is no duty on beer under $2 \%$ alcohol (or under $8 \%$ alcohol if marketed in resusable bottles).

Italy. Beers with a volume of alcohol that does not exceed $0.5 \%$ is not taxed.

Japan. Excise rates are JPY 22000 per hectolitre of product. Small brewers who produce no more than 13 hectolitre of beer per year pay JPY 17600 per hectolitre on the first two hectolitre for the first five years of the license (temporary measure).

Korea. The rate of Liquor Tax on beer is $72 \%$ of the manufacturer's price. In addition, Education Tax (30\% on the amount of Liquor Tax levied) is also levied.

Luxembourg. Rates for small breweries (annual production up to $200000 \mathrm{hl}$ ) range from EUR 0.40 to EUR 0.45.

Mexico. All rates are according to the value. The rates for beer and other alcoholic beverages apply as follows: $25 \%$ up to $14^{\circ} \mathrm{GL}$; $30 \%$ above $14^{\circ} \mathrm{GL}$ and up to $20^{\circ} \mathrm{GL} ; 50 \%$ above $20^{\circ} \mathrm{GL}$. As a mechanism to discourage the use of disposable containers, taxpayers should pay the greater amount between the result of applying the corresponding rate to the value or a $3 \mathrm{MXN}$ per litre fee (taxpayers that use re-usable containers can reduce an amount of 1.26 MXN per litre). 
Netherlands. For beer that is sold usually, that is, beer of 12 degree Plato in the range 11-15 degree Plato (EUR 32.64:12= EUR 2.72 per degree Plato). Excise rates are as follows per hectolitre of product: $a$ ) Up to 7 degree Plato EUR 5.50; $b$ ) 7-11 degree Plato EUR 24.49; c) 11-15 degree Plato EUR 32.64; d) over 15 degree Plato EUR 40.82. Rates for small breweries (annual production up to $200000 \mathrm{hl}$ ) are as follows: a) up to 7 degree Plato the above mentioned rate; $b$ ) 7-11 degree Plato EUR 22.65; c) 11-15 degree Plato EUR 30.19; d) over 15 degree Plato EUR 37.76. For beer with a maximum alcohol content of $0.5 \%$ the VAT rate is $6 \%$.

New Zealand. The excise rate for beer containing more than 2.5\% vol. is NZD 27.206 per litre of alcohol in finished product. The rate for beer containing more than $1.15 \%$ vol. but not more than $2.5 \%$ vol. is NZD 40.802 per litre of product. There is no excise duty on beer containing less than $1.15 \%$ vol.

Norway. Excise rates are as follows per hectolitre of product: a) $0.0-0.7 \%$ vol. NOK $0 ;$ b) $0.7-2.7 \%$ vol. NOK $300 ; c)$ ) $2.7-3.7 \%$ vol. NOK $1131 ; d) 3.7-4.7 \%$ vol. NOK 1959 . The excise rate for beer with an alcoholic content of more than $4.7 \%$ vol. is NOK 438 per degree of alcohol and hectolitre.

Poland. Allowances for small breweries: production $\leq 20000 \mathrm{hl}$ a year tax is reduced by PLN $30 / \mathrm{hl}$; production $\leq 70000 \mathrm{hl}$ a year tax is reduced by PLN 15/hl; production $\leq 150000 \mathrm{hl}$ a year tax is reduced by PLN 12.00/hl and by PLN 9.00/hl if the producer sells no more than $200000 \mathrm{hl}$ a year.

Portugal. Excise rates for beer are as follows per hectolitre of product: a) More than $0.5 \%$ vol. and up to $1.2 \%$ - EUR 7.36 ; $b$ more than $1.2 \%$ vol. and a degree Plato up to 7 - EUR 9.22; c) more than $1.2 \%$ vol. and a degree Plato in excess of 7 but up to 11 - EUR $14.72 ; d$ ) more than $1.2 \%$ vol. and a degree of Plato in excess of 11 but up to 13 - EUR $18.43 ; e$ ) more than $1.2 \%$ vol. and a degree of Plato in excess of 13 but up to 15 - EUR $22.10 ; f$ ) more than $1.2 \%$ vol. and a degree of Plato in excess of $15-$ EUR 25.85. Rates for small breweries (annual production up to $200000 \mathrm{hl}$ ) are $50 \%$ of the normal rates.

Slovenia. Updated information provided by the Slovenian Government, different from the original source of the table. Specific excise per hectolitre per degree alc. is EUR 11 since April 2012.

Spain. Excise rate according to strength is : beer $<1.2 \%$ vol. is free of excise; beer between $1.2 \%$ and $2.8 \%$ vol. is EUR $2.75 / h l$; beer between 2.8\% vol. and 11 degree Plato is EUR 7.48/hl; beer with a degree Plato $>11$ and not $>15=$ EUR 9.96/hl; beer with a degree Plato $>15$ and not $>19=$ EUR 13.56/hl; beer with a degree Plato $>19=$ EUR 0.91/hl and per degree Plato. There is no tax on Beer in Ceuta and Melilla (Spanish cities situated in the North of Africa).

Switzerland. Rates per hectolitre: light beer (up to $10.0^{\circ}$ Plato): CHF 16.88, regular and special beer (10.1 to $14.0^{\circ}$ Plato): CHF 25.32, strong beer (from $14.1^{\circ}$ Plato): CHF 33.76. Reductions for small breweries from $40 \%$ (annual production max. 15 $000 \mathrm{hl}$ ) to $0 \%$ (annual production min. $55000 \mathrm{hl}$ ). Beer with more than $15 \%$ vol. is taxed as an alcoholic beverage (CHF 2900 per hectolitre of absolute alcohol).

Turkey. No specific tax element. The elements according to the value are the Excise Duty at a rate of $63.3 \%$ If the amount computed according to the tax rate is lower than the minimum tax amount specified in the above table, then the minimum tax is paid.

United Kingdom: United Kingdom. Beer with an alcoholic content not exceeding 1.2\% vol. is free of excise. Lower strength beer duty applies to beer 1.3 to $2.8 \%$ alcohol by volume and is equivalent to $50 \%$ of the general beer duty rate. High strength beer duty was introduced from 1 October 2011 and is a duty applied to all beer exceeding $7.5 \%$ alcohol by volume in addition to general beer duty. Reduced duty rates apply for independent breweries producing between 5000 hectolitres and 30000 hectolitres $=$ annual production -2500 /annual production $\times$ standard rate of duty; Between 30000 hectolitres and 60000 hectolitres $=$ annual production $-(2500-8033 \%$ of annual production in excess of 30000$) /$ annual production $\times$ standard rate of duty. No further reduction of the Lower Strength Beer Duty rate can be claimed by a small brewer.

United States. The weighted average Federal and State excise tax rate is USD 22 per hectolitre of product. The Federal tax is USD 18.00 per barrel ( 31 gallons). 1 barrel $=1.1735$ hectolitres. Small domestic brewers who produce less than 2 million barrels of beer per calendar year pay USD 7.00 in federal tax per barrel on the first 60000 barrels. There is no progressive rate structure based on alcohol content and no Federal VAT.y 2010, it is EUR 10.00. 


\begin{tabular}{|c|c|c|c|c|c|c|c|c|c|}
\hline & \multicolumn{3}{|c|}{ Still wine } & \multicolumn{3}{|c|}{ Sparkling wine } & \multicolumn{3}{|c|}{ Low-alcohol (still) wine $(<8.5 \%$ alc $)$} \\
\hline & \multicolumn{2}{|c|}{ Excise per hectolitre of } & \multirow[b]{2}{*}{ VAT rate $(\%)$} & \multicolumn{2}{|c|}{ Excise per hectolitre of } & \multirow[b]{2}{*}{ VAT rate $(\%)$} & \multicolumn{2}{|c|}{ Excise per hectolitre of } & \multirow[b]{2}{*}{ VAT (\%) } \\
\hline & $\begin{array}{l}\text { National } \\
\text { currency }\end{array}$ & USD & & $\begin{array}{l}\text { National } \\
\text { currency }\end{array}$ & USD & & $\begin{array}{l}\text { National } \\
\text { currency }\end{array}$ & USD & \\
\hline Australia & See note & - & 10.0 & See note & & 10.0 & See note & & 10.00 \\
\hline Austria & 0.00 & 0.00 & 20.0 & 0.00 & 0.00 & 20.0 & 0.00 & 0.00 & 20.00 \\
\hline Belgium & 47.10 & 54.39 & 21.0 & 161.13 & 186.06 & 21.0 & 14.87 & 17.17 & 21.00 \\
\hline Canada & 62.00 & 50.43 & $5,12,13$ or 15 & 62.00 & 50.43 & $5,12,13$ or 15 & See note & $=1$ & $5,12,13$ or 15 \\
\hline Chile & See note & & 19.0 & See note & & 19.0 & See note & _ & 19.00 \\
\hline Czech Republic & 0.00 & 0.00 & 20.0 & 2340.00 & 168.11 & 20.0 & 0.00 & 0.00 & 20.00 \\
\hline Denmark & 1062.00 & 135.90 & 25.0 & 1422.00 & 181.97 & 25.0 & 488.00 & 62.45 & 25.00 \\
\hline Estonia & 73.11 & 137.43 & 20.0 & 73.11 & 137.43 & 20.0 & 31.70 & 59.59 & 20.00 \\
\hline Finland & 312.00 & 329.71 & 24.0 & 312.00 & 329.71 & 24.0 & See note & & 24.00 \\
\hline France & 3.60 & 4.15 & 19.6 & 8.91 & 10.28 & 19.6 & 3.60 & 4.15 & 19.60 \\
\hline Germany & 0.00 & 0.00 & 19.0 & 136.00 & 170.40 & 19.0 & 0.00 & 0.00 & 19.00 \\
\hline Greece & 0.00 & 0.00 & 23.0 & 0.00 & 0.00 & 23.0 & 0.00 & 0.00 & 23.00 \\
\hline Hungary & 0.00 & 0.00 & 27.0 & 14960.00 & 115.17 & 27.0 & 0.00 & 0.00 & 27.00 \\
\hline Iceland & See note & & 25.5 & See note & & 25.5 & See note & & 25.50 \\
\hline Ireland & 262.24 & 313.22 & 23.0 & 524.48 & 626.43 & 23.0 & 87.39 & 104.38 & 23.00 \\
\hline Israel & 0.00 & 0.00 & 16.0 & See note & - & 16.0 & 0.00 & 0.00 & 16.00 \\
\hline Italy & 0.00 & 0.00 & 21.0 & 0.00 & 0.00 & 21.0 & 0.00 & 0.00 & 21.00 \\
\hline Japan & 8000.00 & 74.85 & 5.0 & 8000.00 & 74.85 & 5.0 & 8000.00 & 74.85 & 5.00 \\
\hline Korea & See note & & 10.0 & See note & - & 10.0 & See note & & 10.00 \\
\hline Luxembourg & 0.00 & 0.00 & 12 or 15 & 0.00 & 0.00 & 15.0 & 0.00 & 0.00 & 12.00 \\
\hline Mexico & $25 \% / 30 \%$ & - & 16.0 & $25 \% / 30 \%$ & - & 16.0 & $25 \%$ & - & 16.00 \\
\hline Netherlands & 70.56 & 84.80 & 19.0 & 240.58 & 289.12 & 19.0 & 35.28 & 42.40 & 6 or 19 \\
\hline New Zealand & See note & & 15.0 & See note & & 15.0 & See note & & 15.00 \\
\hline Norway & 5256.00 & 546.22 & 25.0 & 5256.00 & 546.22 & 25.0 & See note & - & 25.00 \\
\hline Poland & 158.00 & 84.28 & 23.0 & 158.00 & 84.28 & 23.0 & 158.00 & 84.28 & 23.00 \\
\hline Portugal & 0.00 & 0.00 & 13.0 & 0.00 & 0.00 & 23.0 & 0.00 & 0.00 & 23.00 \\
\hline Slovak Republic & 0.00 & 0.00 & 20.0 & 79.66 & 153.33 & 20.0 & 0.00 & 0.00 & 20.00 \\
\hline Slovenia & 0.00 & 0.00 & 20.0 & 0.00 & 0.00 & 20.0 & 0.00 & 0.00 & 20.00 \\
\hline Spain & 0.00 & 0.00 & 18.0 & 0.00 & 0.00 & 18.0 & 0.00 & 0.00 & 18.00 \\
\hline Sweden & 2158.00 & 242.09 & 25.0 & 2158.00 & 242.09 & 25.0 & 0.00 & 0.00 & 25.00 \\
\hline Switzerland & 0.00 & 0.00 & 8.0 & 0.00 & 0.00 & 8.0 & 0.00 & 0.00 & 8.00 \\
\hline Turkey & See note & - & 18.0 & See note & - & 18.0 & See note & & 18.00 \\
\hline United Kingdom & 241.23 & 365.96 & 20.0 & 308.99 & 468.75 & 20.0 & 74.32 & 112.75 & 20.0 \\
\hline United States & 47.00 & 47.00 & & 115.00 & 115.00 & 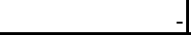 & See note & & \\
\hline
\end{tabular}

\section{Country notes}

Australia. All wine (including still, sparkling and low alcohol wine) are taxed at $10 \%$ by the goods and services tax (GST) and are liable for the wine equalisation tax (WET). WET applies at $29 \%$ of the value of the wine at the last wholesale sale (before adding GST). A rebate of WET applies to eligible producers, up to a maximum of AUD 500000 each financial year.

Canada: 1) A rate of CAD 0.62 per litre applies to wine with more than $7 \%$ absolute ethyl alcohol by volume. The rate is CAD 0.295 per litre on wine of more than $1.2 \%$ absolute ethyl alcohol by volume, but not more than $7 \%$; and for all wine with $1.2 \%$ absolute ethyl alcohol by volume or less the rate is CAD 0.0205 per litre. 2) Fortified wine in excess of $22.9 \%$ absolute ethyl alcohol by volume would not be included in the definition of "wine" (and, therefore, fall within the definition of "spirits").

Chile: The sale of alcoholic beverages (including wine, beer and other distilled and non distilled alcoholic beverages) is subject to $19 \%$ VAT and to a surtax of $15 \%$ on the sale or import of wine, sparkling wine, champagne, cider and other alcoholic beverages (among others). The tax is applied to the VAT base, that is the sale price (excluding VAT itself), and levies sales made between wholesale dealers. For sales between wholesalers, the tax paid to the vendor is creditable against the tax applied on sales at each stage of the value chain (including imports) until the last sale to the final retailer. The sale from the retailer to the

final consumer is not subject to this surtax and the retailer cannot deduct the input tax nor is levied with this tax the sale of wine in bulk made by producers to a VAT taxpayer seller.

Denmark. The rate for wine with more than $15 \%$ - maximum $22 \%$ volume is DKK 1422 . Low-alcohol wine is more than $1.2 \%-$ maximum $6 \%$ volume. Still and sparkling wine is more than $6 \%$ - maximum $15 \%$ volume. The rates for sparkling wine correspond to the rates for still wine plus 306 DKK pr. hectolitre of product. An additional duty is placed on products which contains a mixture of wine and non-alcoholic drinks, Rates: DKK $6.52 \mathrm{pr}$. L of mixture with alcohol content $<=10 \%$ in the final product and DKK 10.52 pr. 1 of mixture with alcohol content $>10 \%$ in the final product.

Finland. Updated information provided by the Finnish Government, different from the original source of the table. Excise rates for low alcohol wine are as follows: a) over $1.2 \%$ vol. and up to $2.8 \%$ vol. EUR $11.00 ; b$ ) over $2.8 \%$ vol. and up to $5.5 \%$ vol. EUR $159.00 ; c$ ) over $5.5 \%$ vol. and up to $8.0 \%$ vol. EUR 224.00 .

France. A reduced rate applies to the following categories of low-alcohol wine: cider, perry, mead, grapes juice lightly sparking. 
Germany. Excise rate for low alcohol sparkling wine $<6 \%$ vol. is EUR 51.00. Intermediate products with a volume of alcoholic degree between $1.2 \%$ and $22 \%$ are taxed according to the following rates: $>15 \%$ vol. $-22 \%$ vol. $=153 \mathrm{EUR} / \mathrm{hl} ;<=15 \%$ vol. $=$ $102 \mathrm{EUR} / \mathrm{hl} ;<=15 \%$ vol. and sparkling $=136 \mathrm{EUR} / \mathrm{hl}$.

Iceland. The duty rate in Iceland is ISK 82.14 per centilitre of alcohol per litre minus 2.25 centilitres for wine up to $15 \%$. For example, one litre of wine that has $15 \%$ alc./vol. has 15 centilitres alcohol per litre. So the duty for one litre of wine that contains $6 \%$ alc./vol. would be as follows: $(15-2.25) * 82.14=$ ISK 1.047 per litre.

Ireland. The rate for low alcohol wine applies to wine with an alcoholic content of less than $5.5 \%$ vol. The rate for still wine with alcoholic content $>15 \%$ alcoholic content is EUR 380.52. Israel. Sparkling wines were taxed at $45 \%$ of the wholesale price until 8 May 2007. There has been no tax levied from 9 May 2007.

Israel. The statistical data for Israel are supplied by and under the responsibility of the relevant Israeli authorities. The use of such data by the OECD is without prejudice to the status of the Golan Heights, East Jerusalem and Israeli settlements in the West Bank under the terms of international law.

Korea. The rate of liquor tax on wine is $30 \%$ on the manufacturer's price (or imported price). In addition, Education Tax (10\% of the amount of Liquor tax levied) is also levied. These rates are applicable to both still and sparkling wine regardless of alcohol content.

Luxembourg. The reduced VAT rate applies to still wine with alcoholic content $\leq 13 \%$ alcoholic content. 
Taxation of Spirits

\begin{tabular}{|c|c|c|c|c|}
\hline & \multicolumn{4}{|c|}{ Tax per hectolitre of absolute alcohol } \\
\hline & \multicolumn{2}{|c|}{ Excise } & \multirow{2}{*}{$\begin{array}{c}\text { VAT rate } \\
\text { (\%) }\end{array}$} & \multirow{2}{*}{$\begin{array}{l}\text { Small distillery } \\
\text { rate }\end{array}$} \\
\hline & National currency & USD & & \\
\hline Australia & 7631.00 & 4896.39 & 10.0 & No \\
\hline Austria & 1000.00 & 1176.96 & 20.0 & Yes \\
\hline Belgium & 1752.24 & 2023.29 & 21.0 & No \\
\hline Canada & 1169.60 & 951.35 & $5.0,12.0,13.0$ or 15.0 & No \\
\hline Chile & See note & - & 19.0 & No \\
\hline Czech Republic & 28500.00 & 2047.45 & 20.0 & No \\
\hline Denmark & 15000.00 & 1919.56 & 25.0 & No \\
\hline Estonia & 1418.00 & 2665.42 & 20.0 & No \\
\hline Finland & 4340.00 & 4586.37 & 24.0 & No \\
\hline France & 1660.00 & 1914.72 & 19.6 & No \\
\hline Germany & 1303.00 & 1632.62 & 19.0 & Yes \\
\hline Greece & 2450.00 & 3462.62 & 23.0 & No \\
\hline Hungary & 289900.00 & 2231.86 & 27.0 & Yes \\
\hline Iceland & 1069300.00 & 7766.22 & 25.5 & No \\
\hline Ireland & 3113.00 & 3718.14 & 23.0 & No \\
\hline Israel & See note & - & 16.0 & No \\
\hline Italy & 800.00 & 1002.00 & 21.0 & No \\
\hline Japan & See note & - & 5.0 & No \\
\hline Korea & See note & - & 10.0 & No \\
\hline Luxembourg & 1041.15 & 1116.06 & 15.0 & No \\
\hline Mexico & $50 \%$ & - & 16.0 & No \\
\hline Netherlands & 1504.00 & 1807.45 & 6.0 or 19.0 & No \\
\hline New Zealand & see note & - & 15.0 & No \\
\hline Norway & 67200.00 & 6983.59 & 25.0 & No \\
\hline Poland & 4960.00 & 2645.79 & 23.0 & No \\
\hline Portugal & 1108.94 & 1755.01 & 23.0 & Yes \\
\hline Slovak Republic & 1080.00 & 2078.73 & 20.0 & No \\
\hline Slovenia & 1200.00 & 1904.90 & 20.0 & No \\
\hline Spain & 830.25 & 1169.48 & 18.0 & Yes \\
\hline Sweden & 50141.00 & 5625.03 & 25.0 & No \\
\hline Switzerland & 2900.00 & 1938.13 & 8.0 & Yes \\
\hline Turkey & 6600.00 & 6337.68 & 18.0 & No \\
\hline United Kingdom & 2552.00 & 3871.49 & 20.0 & No \\
\hline United States & 974.00 & 974.00 & - & No \\
\hline
\end{tabular}

Source: Consumption Tax Trends 2012, OECD

\section{Country notes}

Australia. Updated information provided by the Australian Government, different from the original source of the table. The excise duty rate of AUD 76.31 per litre of alcohol applied to fruit brandy, whisky, rum, liqueurs and other excisable beverages (but not beer) of alcoholic strength exceeding 10\%. Brandy attracted the rate of AUD 71.31 per litre of alcohol and a rate of AUD 76.31 per litre of alcohol applied to other excisable beverages (but not beer) of alcoholic strength not exceeding 10\%. These rates are indexed to inflation in February and August each year.

Austria. For small distilleries producing not more than $4 \mathrm{hl}$ pure alcohol per year the rate EUR 540.

Canada. 1) Spirits are subject to excise duty at the rate of CAD 11.696 per litre of absolute ethyl alcohol by volume. Spirits containing not more than 7\% absolute ethyl alcohol by volume are subject to excise duty at the rate of CAD 0.295 per litre. 2) Beer with an alcoholic strength in excess of $11.9 \%$ absolute ethyl alcohol by volume is deemed to be Spirits. 
Chile. The sale of alcoholic beverages (including wine, beer and other alcoholic beverages) is subject to $19 \%$ VAT and to a surtax on the sale or import of alcoholic beverages, including among others distilled alcoholic beverages. The rates are applied for alcoholic beverages at the following: $27 \%$ on liquors, brandy, vermouth, pisco, whiskey and other distilled alcoholic beverages; $15 \%$ on beer, wine, sparkling wine, champagne, cider and other alcoholic beverages. The tax is applied to the VAT base, that is the sale price (excluding VAT itself) and levies sales made between wholesale dealers. For sales between wholesalers, the tax paid to the vendor is creditable against the tax applied on sales at each stage of the value chain (including imports) until the last sale to the final retailer. The sale from this retailer to the final consumer is not subject to the surtax and the retailer cannot deduct the input tax nor is levied with this tax on the sale of wine in bulk made by producers to a VAT taxpayer seller.

Denmark. An additional duty is placed on products which contain a mixture of spirits and non-alcoholic drinks, Rates: DKK 3.15 per litre of mixture.

Finland. Updated information provided by the Finnish Government, different from the original source of the table. Excise rates are as follows: a) $\mathrm{CN}$ - code 2208. alcoholic content between 1.2\% and 2.8\% vol. EUR 400; b) Other products EUR 4340.

Germany. The rates for small distilleries are EUR 730 or EUR 1022.

Greece. The rate for ouzo and ethyl alcohol (derogation possible for several regions but only applied in the department of Dodecanese) is EUR 1225 per hectolitre of pure alcohol.

Hungary. Reduced rate applies to ethyl-alcohol produced by fruit growers' distilleries from fruit supplied to them by private fruit growers. The application of reduced rate is limited to 50 litres of pure alcohol for private consumption per fruit grower per year.

Iceland. Excise rate shown in the Table is the rate for other alcohol than beer or wine up to $15 \%$. The rate is ISK 106.93 per each centilitre of alcohol by volume exceeding $2.25 \%$.

Israel. The statistical data for Israel are supplied by and under the responsibility of the relevant Israeli authorities. The use of such data by the OECD is without prejudice to the status of the Golan Heights, East Jerusalem and Israeli settlements in the West Bank under the terms of international law. The excise rates for all kinds of alcoholic beverages composed from specific excise of ILS 20.98 per litre of absolute alcohol and from ad valorem excise of $75 \%$ of the wholesale price.

Italy. Taxation applies for beverages of alcoholic strength exceeding $1.2 \%$.

Japan. Excise rates are as follows: $a$ ) Whisky and brandy (40\% vol.) JPY 40 000; b) Spirits (37\% vol.) JPY 37 000; c) Shochu Group A and B (25\% vol.) JPY 25000.

Korea. As Excise Tax for liquor is based on the value of the product, the rate does not vary with alcohol content. For whisky, brandy, general distilled spirits, liqueur, diluted soju and distilled soju, the Liquor tax is $72 \%$ and the Education tax is $30 \%$.

Mexico. The rates for alcoholic beverages apply as follows: $25 \%$ up to $14^{\circ} \mathrm{GL} ; 30 \%$ above $14^{\circ} \mathrm{GL}$ and up to $20^{\circ} \mathrm{GL} ; 50 \%$ above $20^{\circ} \mathrm{GL}$.

Netherlands. For low alcohol spirits with an alcoholic content $<1.2 \%$ the VAT rate is $6 \%$.

New Zealand. For alcoholic beverages with 9-14\% alcoholic content, the excise rate is NZD 2.7206 per litre. For alcoholic beverages above $14 \%$ in alcoholic content, the excise rate is NZD 49.550 per litre of absolute alcohol (with the exception of unfortified wine and vermouth which has the rate of NZD 2.7206 per litre of product).

Portugal. A reduced rate of $50 \%$ for small distilleries applies.

Slovak Republic. A reduced rate, not less than $50 \%$ of the national rate of excise duty on ethyl alcohol, applies to ethyl alcohol produced by fruit growers' distilleries. The application of the reduced rate is limited to 43 litres of ethyl alcohol for personal consumption of the fruit growers' household per year.

Slovenia. Updated information provided by the Slovenian Government, different from the original source of the table. Tax per hectolitre of absolute alcohol until end of June 2010 was 911.00, since 1 July 2010 it is EUR 1000.00 , since April 2012 it is EUR 1200.00

Spain. The excise rate in the Canary Islands is EUR 649.66 per hl of pure alcohol. There is a special regime for small distilleries for which the rate is EUR 726.50 per hl (or EUR 565.66 in the Canary Islands).

Switzerland. Under certain conditions farmers do not pay tax on the first 5 litres of pure alcohol produced per year for their personal consumption. A reduced rate of $30 \%$ is applied to the first 30 litres of pure alcohol produced per year by small producers. Normal rate: CHF 2900 per hectolitre. Special rate for certain types of wines: CHF 1450 per hectolitre. Special rate for alkopops: CHF 11600 per hectolitre (Alkopop - also called ready to drink (RTD) or designer drink) is a mix of alcohol and soda.

Turkey. No specific tax element. The element according to the value is the Excise Duty at a rate of $0 \%$. If the tax amount computed according to the tax rate is lower than the minimum tax amount specified in the official table, then the minimum tax amount is paid.

United Kingdom. All drinks over 22\% alcohol by volume are dutied as spirits. Most other mixtures of spirits with other types of alcohol are also dutied as spirits.

United States. The weighted average Federal and State excise tax rate is USD 923 per hectolitre. The Federal excise rate is USD 13.50 per proof gallon. A proof gallon is a US gallon (3.785 litres) containing 50\% alcohol. There is no Federal VAT. 
Taxation of tobacco

\begin{tabular}{|c|c|c|c|c|c|c|c|c|c|c|c|}
\hline & \multirow[b]{3}{*}{ Currency } & \multicolumn{3}{|c|}{ Cigarettes } & \multicolumn{3}{|c|}{ Cigars $^{2}$} & \multicolumn{3}{|c|}{$\begin{array}{c}\text { Tax on rolling tobacco for } \\
\text { cigarettes }\end{array}$} & \multirow{3}{*}{$\begin{array}{c}\text { VAT } \\
\%\end{array}$} \\
\hline & & \multicolumn{2}{|c|}{\begin{tabular}{|c|} 
Specific excise \\
per 1000 grams
\end{tabular}} & \multirow{2}{*}{\begin{tabular}{|c|}
$\begin{array}{c}\text { Excise on } \\
\text { value }\end{array}$ \\
$(\% \text { of } R S P)^{1}$ \\
\end{tabular}} & \multicolumn{2}{|c|}{$\begin{array}{l}\text { Spe cific excise } \\
\text { per } 1000 \text { grams }\end{array}$} & \multirow{2}{*}{$\begin{array}{c}\begin{array}{c}\text { Excise on } \\
\text { value }\end{array} \\
(\% \text { of } R S P) \\
\end{array}$} & \multicolumn{2}{|c|}{$\begin{array}{l}\text { Specific excise } \\
\text { per } 1000 \text { grams }\end{array}$} & \multirow{2}{*}{$\begin{array}{c}\begin{array}{c}\text { Excise on } \\
\text { value }\end{array} \\
(\% \text { of } R S P) \\
\end{array}$} & \\
\hline & & $\begin{array}{l}\text { National } \\
\text { currency }\end{array}$ & USD & & $\begin{array}{l}\text { National } \\
\text { currency }\end{array}$ & USD & & $\begin{array}{l}\text { National } \\
\text { currency }\end{array}$ & USD & & \\
\hline Australia* & AUD & 446.65 & 286.59 & 0.00 & See note & - & 0.00 & 446.65 & 286.59 & 0.00 & 10.00 \\
\hline Austria* & EUR & 35.00 & 41.19 & 42.00 & 0.00 & 0.00 & 13.00 & 0.00 & 0.00 & 54.00 & 20.00 \\
\hline Belgium & EUR & 15.93 & 18.39 & 52.41 & 0.00 & 0.00 & 10.00 & 7.96 & 9.19 & 31.50 & 21.00 \\
\hline Canada* & CAD & 85.00 & 69.14 & See note & 18.50 & 15.05 & See Note & 57.85 & 47.06 & See note & $5,12,13$ or 15 \\
\hline Chile & CLP & See note & & 62.30 & See note & & 52.60 & See note & & 59.70 & 19.00 \\
\hline Czech Republic & $\mathrm{CZK}$ & 1120.00 & 80.46 & 28.00 & 1250.00 & 89.80 & & 1400.00 & 100.58 & - & 20.00 \\
\hline Denmark* & DKK & 1166.50 & 149.28 & 1.00 & 198.00 & 25.34 & 10.00 & 772.50 & 98.86 & 0.00 & 25.00 \\
\hline Estonia & EUR & 42.18 & 79.29 & 34.72 & 191.73 & 360.40 & 0.00 & 55.79 & 104.87 & 0.00 & 20.00 \\
\hline Finland* & EUR & 22.50 & 23.78 & 52.00 & 0.00 & 0.00 & 27.00 & 16.50 & 17.44 & 52.00 & 24.00 \\
\hline France & EUR & 27.66 & 31.90 & 64.25 & 0.00 & 0.00 & 27.57 & 0.00 & 0.00 & 58.57 & 19.60 \\
\hline Germany & EUR & 92.60 & 116.03 & 21.87 & 14.00 & 17.54 & 1.47 & 43.31 & 54.27 & 14.41 & 19.00 \\
\hline Greece & EUR & 19.66 & 27.79 & 52.45 & 0.00 & 0.00 & 34.00 & 0.00 & 0.00 & 67.00 & 23.00 \\
\hline Hungary & HUF & 10550.00 & 81.22 & 28.40 & 0.00 & 0.00 & 28.50 & 0.00 & 0.00 & 52.00 & 27.00 \\
\hline Iceland & ISK & 18282.00 & 132.78 & 36.50 & See note & - & 36.50 & 1308.00 & 9.50 & 37.60 & 25.50 \\
\hline Ireland & EUR & 192.44 & 229.85 & 18.03 & 271.34 & 324.08 & 0.00 & 228.97 & 273.48 & 0.00 & 23.00 \\
\hline Israel & ILS & 224.99 & 60.68 & See note & 0.00 & 0.00 & See note & 286.69 & 77.32 & 0.00 & 16.00 \\
\hline Italy & EUR & 9.08 & 11.37 & 58.50 & 0.00 & 0.00 & 23.00 & 0.00 & 0.00 & 56.00 & 21.00 \\
\hline Japan* & JPY & 12244.00 & 114.56 & 0.00 & 12244.00 & 114.56 & 0.00 & 12244.00 & 114.56 & 0.00 & 5.00 \\
\hline Korea* & KRW & 32050.00 & 38.95 & 0.00 & See note & 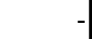 & 0.00 & 23000.00 & 27.95 & 0.00 & 10.00 \\
\hline Luxembourg & EUR & 16.89 & 18.11 & 47.84 & 0.00 & 0.00 & 10.00 & 5.60 & 6.00 & 31.50 & 15.00 \\
\hline Mexico & $\mathrm{MXN}$ & 0.00 & 0.00 & 53.05 & 0.00 & 0.00 & $20.1 / 53.05$ & 0.00 & 0.00 & $20.1 / 53.05$ & 16.00 \\
\hline Netherlands & EUR & 135.66 & 163.03 & 8.59 & 0.00 & 0.00 & 5.00 & 50.45 & 60.63 & 13.00 & 19.00 \\
\hline New Zealand* & NZD & See note & & 0.00 & See note & & 0.00 & 386.14 & 253.49 & 0.00 & 15.00 \\
\hline Norway & NOK & 2310.00 & 240.06 & 0.00 & 2310.00 & 240.06 & 0.00 & 2310.00 & 240.06 & 0.00 & 25.00 \\
\hline Poland & PLN & 170.97 & 91.20 & 31.41 & 254.20 & 135.60 & - & 115.86 & 61.80 & 31.41 & 23.00 \\
\hline Portugal* & EUR & 78.37 & 124.03 & 20.00 & 0.00 & 0.00 & 15.00 & 0.00 & 0.00 & 61.40 & 23.00 \\
\hline Slovak Republic * & EUR & 58.00 & 111.64 & 23.00 & 75.56 & 145.43 & 1 & 69.44 & 133.65 & 0.00 & 20.00 \\
\hline Slovenia & EUR & 21.15 & 33.57 & 45.31 & 0.00 & 0.00 & 5.00 & 40.00 & 63.50 & 0.00 & 20.00 \\
\hline Spain & EUR & 12.70 & 17.89 & 57.00 & 0.00 & 0.00 & 15.80 & 8.00 & 11.27 & 41.50 & 18.00 \\
\hline Sweden & SEK & 1270.00 & 142.47 & 1.00 & 1120.00 & 125.65 & 0.00 & 1560.00 & 175.01 & 0.00 & 25.00 \\
\hline Switzerland* & $\mathrm{CHF}$ & 114.94 & 76.82 & 25.00 & 3.60 & 2.41 & 1.00 & 30.00 & 20.05 & 25.00 & 8.00 \\
\hline Turkey* & TRY & 132.50 & 127.23 & 63.00 & 132.50 & 127.23 & 30.00 & 132.50 & 127.23 & 63.00 & 18.00 \\
\hline United Kingdom & GBP & 154.95 & 235.07 & 16.50 & 193.29 & 293.23 & 0.00 & 151.90 & 230.44 & 0.00 & 20.0 \\
\hline United States* & USD & 129.00 & 129.00 & See note & See note & -1 & -1 & See note & 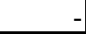 & -1 & \\
\hline
\end{tabular}

Source: Consumption Tax Trends 2012, OECD

Country notes

RSP: Retail selling price.

Cigars: Denmark and Japan tax cigars at a rate per 1000 pieces and not according to weight. In Denmark it is assumed that a cigar weighs 3 grams and in Japan 1 gram.

Australia. Updated information provided by the Australian Government, different from the original source of the table. The excise rate of AUD 0.35731 per stick applies to cigarettes or cigars (in stick form) not exceeding in weight 0.8 grams per stick actual tobacco content. Other tobacco products are subject to an excise rate of AUD 446.65 per kilogram of tobacco content.

Austria. The excise duty on cigars is 13\% of RSP, at least EUR 40.0 for 1000 pieces.

Canada. Canada. The excise duty on cigars is $\$ 18.50$ per 1000 cigars plus an additional excise duty based on the greater of $\$ 0.67$ per cigar and $67 \%$ of the sale price. Each Province and Territory also levies a tobacco tax at varying rates on all tobacco products. Retail sales prices are then subject to GST/HST and, when the HST is not applicable, to a provincial sales tax (excepting Alberta). Chile: The sale of tobacco products are subject to $19 \%$ VAT and to a tax on the sale or import of processed tobacco, cigarettes and cigars. The tax applied to processed tobacco is of $59,7 \%$ on the sale price. Cigarettes are taxed at a rate of $62.3 \%$ over the of the pack' sales price and with an additional rate of 0.0000675 of a Monthly Tax Unit per cigarette contained in the pack (a Monthly Tax Unit equals approximately CLP 31.138 or USD 64.276). Cigars are taxed at a rate of $52.6 \%$. The tax base of the excise tax is the sale' price to the final consumer, including VAT and the tax levied on tobacco, cigarettes and cigars. 
Denmark. Updated information from the European Commission 2013, different from the original source of the table. The excise tax for other smoking tobaccos is DKK $722.5 / 1000 \mathrm{~g}$ for coarse-cut tobacco.

Finland. Updated information provided by the Finnish Government, different from the original source of the table. Cigarette paper: excise $60 \%$ of RSP. Other smoking tobacco: EUR $13.50 / \mathrm{kg}$ and $48 \%$ of RSP. Minimum excise tax is 146 per 1000 pieces for cigarettes and EUR $87.50 / \mathrm{kg}$ for fine cut rolling tobacco for cigarettes.

Hungary. The excise tax for other smoking tobacco is 32.5\%. Minimum excise tax is HUF 1953015175 per 1000 pieces for cigarettes, HUF 87906070 per $\mathrm{kg}$ on rolling and other tobacco. VAT as \% of tax included retail selling price is $21.26 \%$.

Iceland. There is no specific excise rate for a piece of cigars. The rate is ISK 1308 per 1000 grams of cigars (i.e. the same rate as for rolling tobacco).

Israel. The Excises on value for cigarettes and for cigars are $260.6 \%$ and $65 \%$ of the wholesale price, respectively. The statistical data for Israel are supplied by and under the responsibility of the relevant Israeli authorities. The use of such data by the OECD is without prejudice to the status of the Golan Heights, East Jerusalem and Israeli settlements in the West Bank under the terms of international law.

Japan. The tax consists of a national element, a prefectural element and a municipal element.

Korea. The excise tax on cigars is KRW $65400 / 1000 \mathrm{~g}$ and taxation of tobacco is local government excise tax.

Mexico: A rate of $30.4 \%$ (20.1\% of the RSP) for cigars or rolling tobacco applies as long as these products are handmade; otherwise a $160 \%$ rate applies (53.05\% of the RSP).

New Zealand. The excise rate for 1000 cigarettes with actual tobacco content not exceeding in weight of $0.8 \mathrm{~kg}$ is NZD 442.10 . The excise rate for cigarettes exceeding $0.8 \mathrm{~kg}$ in actual tobacco content per 1000 cigarettes is NZD 629.99. The excise rate per kilo of tobacco content for other tobacco products, such as snuff, cigars, cheroots and cigarillos is NZD 552.62.

Portugal. Excise tax on cigarettes is reduced to EUR 8.36 and $36.5 \%$ for small producers in the Azores and Madeira.

Slovenia. If the Retail Selling Price for 1000 cigarettes is EUR 136.50 or less, minimum excise duty (specific + on value) yields EUR 83.00 for 1000 pieces.

Slovak Republic. Tax on rolling tobacco for cigarettes includes other smoking tobacco.

Switzerland: If the Retail Selling Price for 1000 cigarettes is CHF 350.00 or less, minimum excise duty (specific + on value) yields CHF 202.45 for 1000 pieces "Specific excise per $1000 \mathrm{~g}$ for rolling tobacco for cigarettes": the minimum excise duty (specific + on value) yields CHF 50.00 per $1000 \mathrm{~g}$.

Turkey. Specific excise duty per 1000 cigarettes is YTL 60. Tax amount for 1 packet of cigarettes is YTL 1.2. Tax on cigarettes and other tobacco products computed according to proportional basis cannot be less than the tax computed according to minimum specific tax amounts. Excise rate for cigars is YTL 60 for 1000 grams.

United Kingdom. Specific excise rate for cigars is given per kilogramme and not for 1000 units. Specific rates exist for "other smoking tobacco" and "other chewing tobacco" which are currently both set at GBP 84.98 per kilo.

United States. State taxes vary widely. The weighted average of Federal and State taxes per thousand cigarettes is USD 129.00. Federal specific excise tax rates on tobacco are: USD 50.33 per thousand for small cigarettes (no more than 3 pounds per thousand); USD 105.69 per thousand for large cigarettes; USD 50.33 per thousand for small cigars weighing no more than 3 pounds per thousand; $52.75 \%$ of the manufacturers price but not more than USD 402.60 per thousand for large cigars; and USD 24.78 per pound (54.63 per kg) for roll-your own tobacco. Some states also tax on an ad valorem basis. There is no Federal VAT. 


\section{OECD HEALTH WORKING PAPERS}

A full list of the papers in this series can be found on the OECD website: http://www.oecd.org/health/workingpapers

No. 67 MEASURING AND COMPARING HEALTH CARE WAITING TIMES IN OECD COUNTRIES (2013) Luigi Siciliani, Valerie Moran and Michael Borowitz

No. 65 ALCOHOL CONSUMPTION AND HARMFUL DRINKING: TRENDS AND SOCIAL DISPARIETIES IN OECD COUNTRIES (2013) Franco Sassi (Forthcoming)

No. 64 MANAGING HOSPITAL VOLUMES: GERMANY AND EXPERIENCES FROM OECD COUNTRIES (2013) Michael Schoenstein and Ankit Kumar

No. 63 VALUE IN PHARMACEUTICAL PRICING (2013) Valérie Paris, Annalisa Belloni

No. 62 HEALTH WORKFORCE PLANNING IN OECD COUNTRIES: A REVIEW OF 26 PROJECTION MODELS FROM 18 COUNTRIES (2013) Tomoko Ono, Gaetan Lafortune and Michael Schoenstein

No. 61 INTERNATIONAL VARIATIONS IN A SELECTED NUMBER OF SURGICAL PROCEDURES (2013) Klim McPherson, Giorgia Gon, Maggie Scott

No. 60 HEALTH SPENDING GROWTH AT ZERO: WHICH COUNTRIES, WHICH SECTORS ARE MOST AFFECTED? (2013) David Morgan and Roberto Astolfi

No. 59 A COMPARATIVE ANALYSIS OF HEALTH FORECASTING METHODS (2012) Roberto Astolfi, Luca Lorenzoni, Jillian Oderkirk

No. 58 INCOME-RELATED INEQUALITIES IN HEALTH SERVICE UTILISATION IN 19 OECD COUNTRIES, 2008-09 (2012) Marion Devaux and Michael de Looper

No. 57 THE IMPACT OF PAY INCREASES ON NURSES' LABOUR MARKET: A REVIEW OF EVIDENCE FROM FOUR OECD COUNTRIES (2011) James Buchan and Steven Black

No. 56 DESCRIPTION OF ALTERNATIVE APPROACHES TO MEASURE AND PLACE A VALUE ON HOSPITAL PRODUCTS IN SEVEN OECD COUNTRIES (2011) Luca Lorenzoni and Mark Pearson

No. 55 MORTALITY AMENABLE TO HEALTH CARE IN 31 OECD COUNTRIES: ESTIMATES AND METHODOLOGICAL ISSUES (2011) Juan G. Gay, Valerie Paris, Marion Devaux, Michael de Looper

No. 54 NURSES IN ADVANCED ROLES: A DESCRIPTION AND EVALUATION OF EXPERIENCES IN 12 DEVELOPED COUNTRIES (2010) Marie-Laure Delamaire and Gaetan Lafortune

No. 53 COMPARING PRICE LEVELS OF HOSPITAL SERVICE ACROSS COUNTRIES: RESULTS OF A PILOT STUDY (2010) Luca Lorenzoni

No. 52 GUIDELINES FOR IMPROVING THE COMPARABILITY AND AVAILABILITY OF PRIVATE HEALTH EXPENDITURES UNDER THE SYSTEM OF HEALTH ACCOUNTS FRAMEWORK (2010) Ravi P. Rannan-Eliya and Luca Lorenzoni 
No. 51 EFFECTIVE WAYS TO REALISE POLICY REFORMS IN HEALTH SYSTEMS (2010) Jeremy Hurst

No. 50 HEALTH SYSTEMS INSTITUTIONAL CHARACTERISTICS A SURVEY OF 29 OECD COUNTRIES (2010) Valerie Paris, Marion Devaux and Lihan Wei

No. 49 THE CHALLENGE OF FINANCING HEALTH CARE IN THE CURRENT CRISIS (2010) Peter Scherer, Marion Devaux

No. 48 IMPROVING LIFESTYLES, TACKLING OBESITY: THE HEALTH AND ECONOMIC IMPACT OF PREVENTION STRATEGIES (2009) Franco Sassi, Michele Cecchini, Jeremy Lauer and Dan Chisholm

No. 47 HEALTH CARE QUALITY INDICATORS PROJECT: PATIENT SAFETY INDICATORS REPORT 2009 (2009) Saskia Drösler, Patrick Romano, Lihan Wei; and ANNEX Saskia Drösler

No. 46 EDUCATION AND OBESITY IN FOUR OECD COUNTRIES (2009) Franco Sassi, Marion Devaux, Jody Church, Michele Cecchini and Francesca Borgonovi

No. 45 THE OBESITY EPIDEMIC: ANALYSIS OF PAST AND PROJECTED FUTURE TRENDS IN SELECTED OECD COUNTRIES (2009) Franco Sassi, Marion Devaux, Michele Cecchini and Elena Rusticelli

No. 44 THE LONG-TERM CARE WORKFORCE: OVERVIEW AND STRATEGIES TO ADAPT SUPPLY TO A GROWING DEMAND (2009) Rie Fujisawa and Francesca Colombo

No. 43 MEASURING DISPARITIES IN HEALTH STATUS AND IN ACCESS AND USE OF HEALTH CARE IN OECD COUNTRIES (2009) Michael de Looper and Gaetan Lafortune

No. 42 POLICIES FOR HEALTHY AGEING: AN OVERVIEW (2009) Howard Oxley

No. 41 THE REMUNERATION OF GENERAL PRACTITIONERS AND SPECIALISTS IN 14 OECD COUNTRIES: WHAT ARE THE FACTORS EXPLAINING VARIATIONS ACROSS COUNTRIES? (2008) Rie Fujisawa and Gaetan Lafortune

No. 40 INTERNATIONAL MOBILITY OF HEALTH PROFESSIONALS AND HEALTH WORKFORCE MANAGEMENT IN CANADA: MYTHS AND REALITIES (2008) Jean-Christophe Dumont, Pascal Zurn, Jody Church and Christine Le Thi

No. 39 PHARMACEUTICAL PRICING \& REIMBURSEMENT POLICIES IN GERMANY (2008) Valérie Paris and Elizabeth Docteur

No. 38 MIGRATION OF HEALTH WORKERS: THE UK PERSPECTIVE TO 2006 (2008) James Buchan, Susanna Baldwin and Miranda Munro

No. 37 THE US PHYSICIAN WORKFORCE: WHERE DO WE STAND? (2008) Richard A. Cooper 
DELSA/HEA/WD/HWP(2013)7

\section{RECENT RELATED OECD PUBLICATIONS}

HEALTH AT A GLANCE 2013: OECD INDICATORS (2013)

See http://www.oecd.org/health/healthataglance for more information

CANCER CARE - ASSURING QUALITY TO IMPROVE SURVIVAL (2013)

A GOOD LIFE IN OLD AGE? MONITORING AND IMPROVING QUALITY IN LONG-TERM CARE (2013)

STRENGTHENING HEALTH INFORMATION INFRASTRUCTURE FOR HEALTH CARE QUALITY GOVERNANCE (2013)

WAITING TIME POLICIES IN THE HEALTH SECTOR, WHAT WORKS? (2013)

OECD REVIEWS OF HEALTH CARE QUALITY - SWEDEN (2013)

OECD REVIEWS OF HEALTH CARE QUALITY - DENMARK (2013)

OECD HEALTH DATA 2013

(Database available from http://www.oecd.org/els/health-systems/oecdhealthdata.htm)

ICTS AND THE HEALTH SECTOR - TOWARDS SMARTER HEALTH AND WELLNESS MODELS (2013)

HEALTH AT A GLANCE: ASIA/PACIFIC (2012)

HEALTH AT A GLANCE: EUROPE (2012)

OECD REVIEWS OF HEALTH SYSTEMS - RUSSIAN FEDERATION (2012)

OECD REVIEWS OF HEALTH CARE QUALITY - KOREA (2012)

OECD REVIEWS OF HEALTH CARE QUALITY - ISRAEL (2012)

SICK ON THE JOB? MYTHS AND REALITIES ABOUT MENTAL HEALTH AND WORK (2011)

OECD REVIEWS OF HEALTH SYSTEMS - SWITZERLAND (2011)

HEALTH REFORM: MEETING THE CHALLENGE OF AGEING AND MULTIPLE MORBIDITIES (2011)

A SYSTEM OF HEALTH ACCOUNTS (2011)

HELP WANTED? PROVIDING AND PAYING FOR LONG-TERM CARE (2011)

IMPROVING VALUE IN HEALTH CARE: MEASURING QUALITY (2010)

OBESITY AND THE ECONOMICS OF PREVENTION: FIT NOT FAT (2010)

For a full list, consult the OECD On-Line Bookstore at www.oecd.org, or write for a free written catalogue to the following address: OECD Publications Service

2, rue André-Pascal, 75775 PARIS CEDEX 16 or to the OECD Distributor in your country 